\title{
Reproductive success, selected nest characteristics and the effectiveness of es- tablishing protection zones of the lesser spotted eagle (Aquila pomarina) population in Slovakia
}

\author{
Reprodukčná úspešnost', vybrané hniezdne charakteristiky a efektívnost' vyhlasovania \\ ochranných zón u populácie orla krikl'avého (Aquila pomarina) na Slovensku
}

\author{
Miroslav DRAVECKÝ, Boris MADERIČ, Ján KICKO, Štefan DANKO, Dušan KARASKA, \\ Jozef MIHÓK \& Zuzana GUZIOVÁ
}

\begin{abstract}
In 2011-2014 monitoring of the lesser spotted eagle (Aquila pomarina) breeding population was conducted in eight special protection areas in Slovakia. From a total of 272 successful breeding attempts by 149 breeding pairs during 4 breeding seasons 277 young birds were fledged. The average reproductive success ratio was thus $0.51 \mathrm{juv} . / \mathrm{pair}$ present, $0.69 \mathrm{juv}$./breeding pair and $1.37 \mathrm{juv} . / 100 \mathrm{~km}^{2}$. In the surveyed period a total of 151 protection zones were established around the nests in 119 breeding territories, which provided protection for $17 \%$ of the breeding population of the lesser spotted eagle in Slovakia. By testing the effectiveness of protection zones it was determined that in nests with an established protection zone the probability of successful raising of young is higher in comparison with nests without such a zone. The probability that breeding will be successful in the nests of breeding pairs without a protection zone was $48.1 \%$ (95\% confidence intervals (CIs): $37.4-59.0 \%$ ), and in nests with a protection zone $64.8 \%$ (95\% CIs: 59.8-69.6\%). Among the five most frequent nest tree species used by $A$. pomarina in Slovakia for breeding are Picea abies $61 \times(28.4 \%)$, Pinus sylvestris $45 \times(20.9 \%)$, Quercus sp. $36 \times(16.7 \%)$, Fagus sylvatica $25 \times(11.6 \%)$ and Abies alba $18 \times(8.4 \%)$. Among the rarer nest tree species used are Larix decidua $12 \times(5.6 \%)$ and Alnus glutinosa $3 \times(1.4 \%)$, while a further 11 species of nest trees did not achieve even $1 \%$. The highest number of nest trees $(\mathrm{n}=215)$, i.e. 34 nests $(15.8 \%)$, was found in the altitude range of 401-450 m a.s.1. and 29 nests $(13.5 \%)$ at 351-400 $\mathrm{m}$ a.s.1. Other altitude zones were all below the $10 \%$ mark. A total of $54 \%$ of nests found (116 nests) are located in the altitude zone of 301-600 m a.s.1., and 71 nests (33\%) in the zone 600-900 m a.s.l. The lowest situated nest was at an altitude of $150 \mathrm{~m}$ and the highest at $950 \mathrm{~m}$; the average was $595.01 \mathrm{~m}$ a.s.1. The highest number of nests $(\mathrm{n}=209)$ were located on trees in a range $15.1-20.0 \mathrm{~m}$ above the ground $(\mathrm{n}=92$, $44 \%$ ), while the lowest nest found was at a height of $5 \mathrm{~m}$ and the highest at $30 \mathrm{~m}$ above the ground.
\end{abstract}

Abstrakt: V rokoch 2011 - 2014 sa realizoval monitoring hniezdnej populácie orla krikl'avého (Aquila pomarina) v ôsmich chránených vtáčích územiach na Slovensku. U 149 hniezdnych párov z celkových 272 úspešných hniezdení počas 4 hniezdnych sezón vyletelo 277 mlád’at. Priemerná reprodukčná úspešnost' predstavovala 0,51 juv./prítomný pár, 0,69 juv./hniezdiaci pár a 1,37 juv./100 km². V uvedenom období bolo okolo hniezd orlov krikl'avých ustanovených celkom 151 ochranných zón, ktoré zabezpečili ochranu 119 hniezdnych teritórií, čo predstavuje cca 17 \% hniezdnej populácie orla krikl’avého na Slovensku. Testovaním účinnosti ochranných zón sa zistilo, že v hniezdach s vyhlásenou ochrannou zónou je vyššia pravdepodobnost' úspešného odchovania mlád'at v porovnaní s hniezdami bez takejto zóny. Pravdepodobnost', že hniezdenie bude úspešné v hniezdach hniezdiacich párov bez ochrannej zóny bola 48.1\% (95\%konfidenčný interval (CIs): 37.4-59.0\%), v hniezdach s ochrannou zónou 64.8\% (95\% CIs: 59.8-69.6\%). Medzi 5 najčastejšie využívaných hniezdnych stromov na hniezdenie $A$. pomarina na Slovensku patrí Picea abies $61 \times(28,4 \%)$, Pinus sylvestris $45 \times(20,9 \%)$, Quercus sp. 36× (16,7\%), Fagus sylvatica 25× (11,6\%) a Abies alba $18 \times(8,4 \%)$. Medzi zriedkavejšie druhy hniezdnych stromov patrí Larix decidua $12 \times(5,6 \%)$ a Alnus glutinosa $3 \times$ $(1,4 \%)$, d'alších 11 druhov hniezdnych stromov nedosiahli $1 \%$. Najvyšší počet hniezdnych stromov $(\mathrm{n}=215)$, tj. 34 hniezd $(15,8 \%)$ sa nachádzal v intervale nadmorskej výšky $401-450$ m a 29 hniezd $(13,5 \%)$ v intervale $351-400$ m n. m. Ostatné výškové pásma boli pod hranicou 10\%. 54\% zistených hniezd (116 hniezd) sa nachádza vo výškovom pásme $301-600 \mathrm{~m}$ n. $\mathrm{m}$., 71 hniezd $(33 \%)$ v pásme 600 - $900 \mathrm{~m} \mathrm{n}$. m. Najnižšie situované hniezdo bolo v nadmorskej výške $150 \mathrm{~m}$ a najvyššie $950 \mathrm{~m}$, priemer bol 595,01 m. Najvyšší počet hniezd $(\mathrm{n}=209)$ bol na strome umiestnený v rozmedzí 15,1 - 20,0 m $(\mathrm{n}=92,44,02 \%)$. Najnižšie zistené hniezdo bolo vo výške $5 \mathrm{~m}$ a najvyššie $30 \mathrm{~m}$ nad zemou.

Key words: breeding, nests, nest trees, altitude, orographic units, buffer zones, conservation

Miroslav Dravecký, Boris Maderič, Štefan Danko, Zuzana Guziovát, Raptor Protection of Slovakia, Kuklovská 5, SK-841 04 Bratislava, Slovakia. E-mail: dravecky@dravce.sk, maderic@dravce.sk, dankostef@gmail.com,guziova@dravce.sk. 
Ján Kicko, Podtureň 506, SK-033 01 Liptovský Hrádok, Slovakia. E-mail: jano.kicko@gmail.com.

Dušan Karaska, Stodolisko 261, SK-027 41 Oravský Podzámok, Slovakia. E-mail: karaska@vtaky.sk.

Jozef Mihók, Buzulucká 23, 04022 Košice. E-mail: jozef.mihok.ke@gmail.com.

Acknowledgements: Monitoring of the lesser spotted eagle breeding population was performed in the scope of project LIFE09NAT/SK/000396 "Conservation of Aquila pomarina in Slovakia", which was carried out by Raptor Protection of Slovakia in cooperation with the companies Východoslovenská energetika Holding, a.s., Stredoslovenská energetika, a.s. and Stredoslovenská energetika - Distribúcia, a.s. in the years 2011-2015. The project was co-financed by the European Union through its financial instrument for the environment, LIFE, and the Ministry of Environment of the Slovak Republic. Our thanks go to all those who cooperated and who during this project shared in the acquisition of knowledge on the biology of the lesser spotted eagle. They are: Ivana Fabianová, Tomáš Flajs, Ján Hol'ma, Ervín Hrtan Jr., Miroslav Lehocký, Miroslav Madera, Milan Olekšák, Slavomír Senk, Oldřich Suchánek, Peter Vrlík and Ján Žigraj. Our heartfelt thanks also go to Alexander Kürthy for preparation of the maps and to Benjamín Jarčuška for statistical processing of the results on the effectiveness of the established protection zones and for his invaluable comments during the writing of this manuscript.

\section{Introduction}

The lesser spotted eagle (Aquila pomarina) is, according to Birds in Europe: Their Conservation Status and The EBCC Atlas of European Breeding Birds - Their Distribution and Abundance, assigned to the "SPEC 3" category of species (SPECs - Species of European Conservation Concern; SPEC 3 - Species with an unfavourable European conservation status, but with less than half of the global breeding or wintering population within Europe). However, according to data on the decline of the population it was re-categorized to "SPEC 2" (Species with an unfavourable European conservation status and with more than half of the global breeding or wintering population concentrated in Europe; Tucker \& Heath 1994, Hagemeijer \& Blair 1997), among receding species whose breeding populations are concentrated in Europe and whose conservation status in Europe is unfavourable (BirdLife International 2004, 2015). The lesser spotted eagle is listed in Annex 1 of the Birds Directive (2009/147/ES). On the Red List of world birds it is assigned to the category "least concern" (LC) (BirdLife International 2015), and on the Red List of birds of Slovakia it is included among the "nearly threatened" (NT) species (Demko et al. 2013).

In Slovakia in 2002, on the basis of an evaluation performed from 1980-1999 based on the mapping of the distribution of birds in Slovakia (Danko et al. 2002), the occurrence of 800-900 breeding pairs of lesser spotted eagles was assumed (Karaska \& Danko 2002). However, as of 2013 the abundance of the breeding population was estimated at $600-800$ pairs; thus, a $23 \%$ decline was recorded (Dravecký et al. 2015).

Within the project LIFE09NAT/SK/000396 Conservation of Aquila pomarina in Slovakia (hereinafter only the "LIFE project") in 2011-2014, monitoring of the lesser spotted eagle (Aquila pomarina) breeding population was conducted in eight special protection areas (SPAs) (Dravecký et al. 2011, 2012, 2013, 2014). The purpose of the monitoring was to acquire information about the reproductive success of the population in the individual SPAs that together form the LIFE project area, about factors that have a negative impact on the breeding and the quality of the habitat of the eagles, and the effectiveness of the applied conservation measures. The main aim of the LIFE project was in the short-term horizont to stabilize the national population of the lesser spotted eagle by improving its conservation in Slovakia and thus significantly contribute to conservation of the European population of this species.

The aim of this paper is to compare the belowpresented ecological and nest characteristics of the population of the lesser spotted eagle recorded in 2011-2014 in the eight SPAs concerned, namely: 1) abundance, distribution and density, 2) reproductive success, 3) representation of nest tree species, altitude of nest trees, and height of nests from the ground, 4) effectiveness of establishing protection zones.

Due to the impact of intensive human activities, extensive changes have occurred in the past decades in the breeding and feeding habitats of the lesser spotted eagle in Slovakia. The consequence of these changes has been an overall decline in the abundance of the national population of this species. And despite long years and relatively intensive monitoring of the lesser spotted eagle in Slovakia, data is lacking in the published literature on its reproductive success in the SPAs concerned, expressed by the number of juv./pair present, number of juv./breeding pairs, but mainly by the number of juv. $/ 100 \mathrm{~km}^{2}$. With the exception of the work of Kicko 
(2013) there is likewise in Slovakia a lack of published data on the nest characteristics of the species. On the national level and also abroad information on the effectiveness of establishing protection zones around the nests of the eagles is almost completely absent. The results of the study presented herein should enrich knowledge about this species specifically in this area.

Des c ription of surveyed a re a The Horná Orava SPA (SKCHVU008; Fig. 1) is situated at an altitude of $600-1,725 \mathrm{~m}$ a.s.l. in the northwestern part of Slovakia in the Oravské Beskydy Mts, Kysucká vrchovina Uplands, Podbeskydská brázda Gap, Oravská Magura Mts, Podbeskydská vrchovina Uplands and the Oravská kotlina Basin orographic units. This SPA has an area of 58,735 hectares comprising parts of the districts of Dolný Kubín, Námestovo and Tvrdošín. The hilly landscape of this SPA inhabited by the lesser spotted eagle consists of a mosaic of woods, meadows and pastures, and a small extent of fields and marshes at heights above sea level ranging from 600 to 950 metres. The breeding habitats are mainly spruce forests, but exceptionally include also marshy spruce/pine woods. Representation of habitats: urban habitats $3.5 \%$, intensively used agricultural landscape $11 \%$, mosaic agricultural landscape $10 \%$, meadows and pastures $20 \%$, deciduous forests $0.5 \%$, coniferous forests $44 \%$, mixed forests $1 \%$, transitional forest habitats $3 \%$, aquatic habitats (rivers, ponds, marshes, etc.) $6 \%$ and other habitats $1 \%$.
The Tatry Mts SPA (SKCHVU030) is situated at an altitude of 700-2,597 $\mathrm{m}$ a.s.l. in the northern part of central Slovakia in the Západné Tatry Mts, Vysoké Tatry Mts, Belianské Tatry Mts orographic units, and partially extending into the Liptovská kotlina Basin and the eastern part of the Podtatranská brázda Gap. This SPA has an area of 54,611 hectares comprising parts of the districts of Liptovský Mikuláš, Poprad and Tvrdošín. The Tatry Mts SPA consists of high mountain relief with great vertical complexity. The lesser spotted eagle inhabits only the marginal parts of this area, mainly the southern foothills at heights between 700-1100 metres above sea level, bordering on the open spaces of the Liptovská kotlina Basin, which the eagles use as their hunting grounds. These eagles avoid the other parts of the SPA rising above 1,100 metres. The breeding habitats are mainly spruce forests making up not only the forested areas of the lower slopes, but also patches of woodland growing on the farmland below, particularly the permanent grasslands which have become overgrown and now have the character of woods. The nesting by lesser spotted eagles in the Tatry SPA is concentrated in the marginal parts close to agriculturally used land and grassland areas. Representation of habitats: a mosaic agricultural landscape 3\%, meadows and pastures $18 \%$, coniferous forests $43 \%$, mixed forests $2 \%$, transitional forest habitats $21 \%$, aquatic habitats (rivers, ponds, swamps, etc.) $1 \%$, rocky habitats (rock quarries, debris, etc.) $9 \%$ and other habitats $3 \%$.
Fig. 1. Schematic depiction of the location of eight SPAs in Slovakia: Horná Orava (1), Tatry Mts (2), Nízke Tatry Mts (3), Slovenský kras Mts (4), Volovské vrchy Mts (5), Slanské vrchy Mts (6), Vihorlatské vrchy Mts (7) and Laborecká vrchovina Uplands (8). Solid line - boundary of the current distribution of $A$. pomarina in Slovakia as of 2014.

Obr. 1. Schématické znázornenie lokalizácie ôsmich CHVÚ na území Slovenska: Horná Orava (1), Tatry (2), Nízke Tatry (3), Slovenský kras (4), Volovské vrchy (5), Slanské vrchy (6), Vihorlatské vrchy (7) a Laborecká vrchovina (8). Plná čiara - hranica súčasného rozšírenia $A$. pomarina na Slovensku k roku 2014.

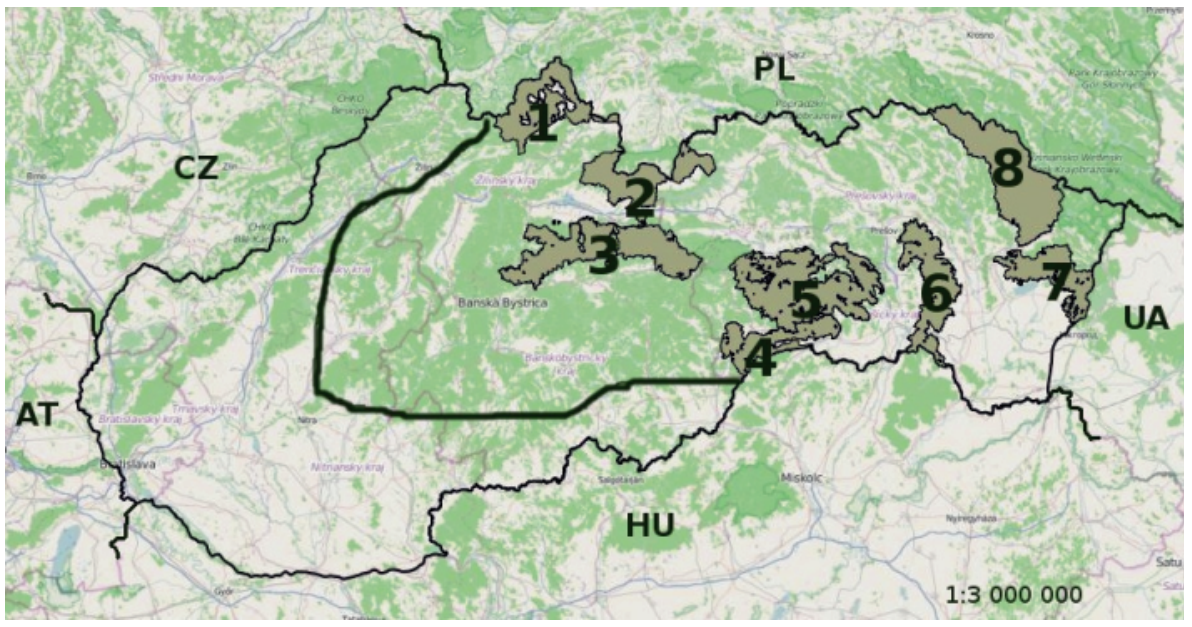


The Nízke Tatry Mts SPA (SKCHVU018) is situated at an altitude of 520-2,040 $\mathrm{m}$ a.s.1. in central Slovakia in the Dumbierske Tatry Mts, Král'ovohol'ské Tatry Mts and Starohorské vrchy Hills orographic units, partially in the Kozie chrbty Mts, and only marginally in the Horehronské Podolie Valley and Slovenský raj Mts areas. This SPA has an area of 98,169 hectares comprising parts of the districts of Banská Bystrica, Brezno, Liptovský Mikuláš, Poprad and Ružomberok. The Nízke Tatry Mts SPA consists of a switchback range of fell-like mountains with predominantly coniferous forests on the north-facing slopes and more mixed woodland on the south-facing slopes. The lesser spotted eagle inhabits only the marginal northern parts of this area at heights between 700-1,200 metres above sea level, bordering on the open spaces of the Liptovská and Popradská kotlina Basins, which the eagles use as their hunting grounds. These eagles avoid the other parts of the SPA rising above 1,300 metres. Several pairs have disappeared completely, and a trend has developed of gradual movement of the remaining pairs to the most marginal parts of the mountain range, or even to the neighbouring lowlands outside the SPA itself. The breeding habitats are spruce forests. The nesting of lesser spotted eagles in the Nízke Tatry Mts SPA is concentrated in the marginal northern parts close to agriculturally-used land and grassland areas. Representation of habitats: intensively used agricultural landscape $1 \%$, mosaic agricultural landscape $5 \%$, meadows and pastures $10 \%$, coniferous forests $53 \%$, mixed forests $9 \%$, a transitional forest habitats $15 \%$, aquatic habitats $0.5 \%$, rocky habitats $2 \%$ and other habitats $3.5 \%$.

The Slovenský kras Mts SPA (SKCHVU027) is situated at an altitude of 185-1030 m a.s.l. and extends into the following orographic zones: Slovenský kras Mts, Košická kotlina Basin, Volovské vrchy Mts and Revúcka vrchovina Uplands. This SPA has an area of 43,860 hectares comprising parts of the districts of Rožňava and Košice-environs. In this area the lesser spotted eagle inhabits a karst landscape at heights above sea level ranging from 220 to 850 metres consisting of plateaux separated by valleys and canyons. The complex, varied relief is complemented in the valleys with fields, meadows and pastures, marshland, fishpools and streams, and with orchards and vineyards on the hillsides. The typical breeding habitat consists of hornbeam and oak woods, beech and mixed beech/hornbeam woodland, then rocky communities of maple, ash, and Scots and black pine. Representation of habitats: urban habitats $1 \%$, intensively used agricultural landscape $4 \%$, mosaic agricultural land $14 \%$, orchards and vineyards $1 \%$, grassland $3 \%$, deciduous forests $51 \%$, coniferous forests $1 \%$, mixed forests $3 \%$, transitional forest habitats $14 \%$, aquatic habitats (rivers, ponds, swamps, etc.) $1 \%$, rocky habitats (rock quarries, debris, etc.) $4 \%$ and other habitats $3 \%$.

The Volovské vrchy Mts SPA (SKCHVU036) is located at an altitude of $240-1,322 \mathrm{~m}$ in the central part of eastern Slovakia, directly adjacent to the Slovenský kras Mts SPA and extending into the Volovské vrchy Mts and Čierna hora Mts orographic units. This SPA has an area of 121,421 hectares comprising parts of the districts of Rožňava, Košice-environs, Spišská Nová Ves, Gelnica and Prešov. The lesser spotted eagle inhabits predominantly the margins of the area, bordering the open spaces of the Hornádska kotlina Basin to the north and the Košická kotlina Basin to the south-east, at heights above sea level ranging from 230 to 900 metres. The eagle avoids the central parts of the SPA rising above 1,000 metres. The breeding habitats consist mainly of coniferous woodland, more spruce forest in the west and fir forest in the central part, mixed forest with beech and oak together with Scots pine, hornbeam and alder in the southern part, and deciduous woodland with beech in the east of the area, together making up around $70 \%$ of the SPA area. Representation of habitats: urban habitats $2 \%$, intensively used agricultural landscape $3 \%$, mosaic agricultural landscape $7 \%$, orchards and vineyards $1 \%$, meadows and pastures $12 \%$, deciduous forests $18 \%$, coniferous forests $26 \%$, mixed forests $26 \%$, transitional forest $2 \%$, aquatic habitats (rivers, ponds, marshes, etc.) $2 \%$ and rocky habitats (rocks, quarries, rubble, etc.) $1 \%$.

The Slanské vrchy Mts SPA (SKCHVU025) is located at an altitude of 140-1,091 m a.s.l. in eastern Slovakia in the Slanské vrchy Mts orographic unit. This SPA has an area of 60,247 hectares comprising parts of the districts of Košice-environs, Prešov, Trebišov and Vranov nad Topl'ou. The hills in this area are of volcanic origin and are inhabited by the lesser spotted eagle at heights from 230 to 900 metres above sea level. The extensive forests covering the hills are complemented on the lower slopes with agricultural land, i.e. ploughed fields, meadows and pastures. Mountain-type meadows are present to a small extent in the area. The breeding habitats consist mainly of beech forests, but also mixed oak and beech woodland with oak stands. Nesting by lesser spotted eagles in the Slanské vrchy Mts SPA is concentrated in the marginal parts of the range in the 
vicinity of agriculturally used lands (arable land and grasslands). Representation of habitats: urban habitats $1 \%$, intensively used agricultural landscape $5 \%$, mosaic agriculturally country $10 \%$, meadows and pastures $7 \%$, deciduous forests $58 \%$, mixed forests $1 \%$, transitional forest habitats $15 \%$, rocky habitats (rocks, quarries, debris, etc.) $1 \%$ and other habitats $2 \%$.

The Vihorlatské vrchy Mts SPA (SKCHVU035) is located at an altitude of 118 to $1,075.5 \mathrm{~m}$ a.s.l. in eastern Slovakia mostly in the Vihorlatské vrchy Mts orographic unit, and partially extending into the Beskydské predhorie Foothills to the north and into the Východoslovenska pahorkatina Uplands to the south. This SPA has an area of 48,286 hectares comprising parts of the districts of Humenné, Michalovce, Snina and Sobrance. The Vihorlatské vrchy Mts are of volcanic origin and are inhabited by the lesser spotted eagle at heights from 120 to 900 metres above sea level. The extensive forests covering the hills give way on the lower slopes to agricultural land, i.e. ploughed fields, meadows and pastures. Mountain-type meadows are present to a small extent in the area. The breeding habitats consist mainly of beech forests, but also mixed oak and beech woodland with oak stands. Nesting by lesser spotted eagles in the Vihorlatské vrchy Mts SPA is concentrated in the marginal parts of the mountain range in the vicinity of agriculturally used lands (arable land and grasslands). Representation of habitats: urban habitats $1 \%$, intensively used agricultural landscape $5 \%$, mosaic agricultural land $10 \%$, orchards and vineyards $1 \%$, meadows and pastures $5 \%$, deciduous forests $62 \%$, mixed forests $2 \%$, transitional forest habitats $10 \%$, rocky habitats (rock quarries, debris, etc.) $1 \%$ and other habitats $1 \%$.

The Laborecká vrchovina Uplands SPA (SKCHVU011) is located at an altitude of $160-880 \mathrm{~m}$ a.s.l. in the north-eastern part of Slovakia, mostly within the Laborecká vrchovina orographic unit, with a small part extending to the south-west into the Ondavská vrchovina Uplands orographic unit. This SPA has an area of 102,814 hectares comprising parts of the districts of Svidník, Stropkov, Medzilaborce, Humenné and Snina. The hilly landscape of this SPA inhabited by the lesser spotted eagle consists of a mosaic of woods, meadows, pastures, fields and marshes and stream system made up of the Svidničanka, Ladomírka, Chotčianka, Ol'ka, Výrava, Udava, Cirocha and Laborec streams, at heights above sea level ranging from 200 to 700 metres. The typical breeding habitat consists of beech and mixed beech/hornbeam woodland. Representation of habitats: urban habitats $1 \%$, intensively used agricultural landscape 4\%, mosaic agricultural landscape $19 \%$, meadows and pastures $10 \%$, deciduous forests $44 \%$, mixed forests $2 \%$, transitional forest habitats $17 \%$, aquatic habitats $1 \%$ and other habitats $2 \%$.

\section{Methods}

Monitoring of the breeding territories of the lesser spotted eagles was carried out from March 1, 2011, to December 31, 2014, in the above-mentioned eight SPAs (Fig. 1). These SPAs are representative examples of different areas of central and eastern Slovakia, with different natural conditions for the breeding population of the lesser spotted eagle, which in the surveyed areas are differentiated by their elevations, share of forested and non-forested surfaces, character of the forests, composition of its trees and other ecological characteristics.

All known breeding territories (BT) in the eight SPAs were monitored. If the presence of a breeding pair was not confirmed in the BT, then it was excluded from the monitoring, and subsequently, if in subsequent years the occurrence of a new breeding pair was confirmed in the SPA, its BT was assigned to the subsequent monitoring. The aim was to determine the actual number of breeding pairs in each SPA as of the end of the monitoring in 2014. BT were mainly monitored within the SPA, but BT outside the SPA, being a part of the home ranges extending into the SPA, were also monitored. Overall, $187 \mathrm{BT}$ were incorporated into the monitoring, from this: in $2011-152 \mathrm{BT}, 2012-163 \mathrm{BT}, 2013-158 \mathrm{BT}$ and $2014-172 \mathrm{BT}$, which represent on average $161 \mathrm{BT}$ in one breeding season. From the total number of 187 BT, in 170 BT (90.9\%) the presence of a breeding pair (BP) was confirmed in at least one year of monitoring and for $17 \mathrm{BT}(9.1 \%)$ the presence of a BP was not confirmed in even one year of monitoring. For $170(100 \%)$ pairs present, the occupied nest was found in at least one year of the monitoring in 149 of the breeding pairs $(87.65 \%)$, and in the case of 21 pairs $(12.35 \%)$ the nest was not found in even one year of the monitoring. In each year of the monitoring these same BT or BP were checked in order to give a year-on-year evaluation of the variability in abundance, density and reproductive success of the individual populations in these areas.

In seven SPAs monitoring was performed over the entire area; in the Slanské vrchy Mts SPA monitoring was conducted only in the southern part, in quadrants 7294, 7295, 7394, 7395, 7494 and 7495 of the Databank 
of Slovak Fauna (DFS) (Kroupová 1980, Stloukal 2001). The size of the relevant surface of the monitored area in Slanské vrchy Mts SPA was $284 \mathrm{~km}^{2}$. This surface was then used for determining the density of the population for this part of the SPA (Slanské vrchy Mts South).

According to the methodology, four checks of each BT were usually performed each year. In some cases the number of checks was altered according to the actual situation (in the range of 2-8), e.g. for reason that the nest could not be found despite repeated flying to the forest of adult eagles carrying prey to young in the nest, or monitoring on the given day was not completed because of unfavourable weather, or breeding was disrupted and the occurrence and movement of the eagles to the BT was uncertain or due to some other reasons.

First check: from February 1 to March 31: The first checks were performed with the aim of evaluating the state of the breeding habitat, the status of the nests and whether quiet was ensured at the breeding territory before the arrival of the eagles. It was determined whether or not forest management activities were taking place in the BT or possibly other activities which could negatively endanger the process of breeding or disturb the condition of the breeding habitat. Not only was the condition of the nests that were occupied by eagles in the preceding year surveyed, but also the state of all nests situated in the home range of the pairs which the eagles occupied in the past five years.

Second check: from April 1 to June 30 (exceptionally until September 30): The occupancy of BT and nest by pairs of eagles were surveyed. Localization of occupied nests was important for determining the conservation regime in the breeding territories in the given year.

Surveying of the occupancy of BT was performed:

a) In the period of courting flights, when it was possible to determine both individuals from the pair most easily and when it was also possible to record pairs which later bred unsuccessfully and subsequently no longer had to stay in their breeding territory.

b) In the incubation period the occupancy of the BT by eagles was surveyed by a check from observation points of the situation in the feeding territory of the pair. The result of the surveying was the registration of the pair of eagles or an individual from the pair at a breeding or feeding site and observing their flying to the breeding forest with known nests.

c) By registration of a male flying over carrying prey to the female in the breeding forest with the as- sumed nest or registration of a common flying over of both individuals from the pair to the area with the assumed nest.

d) By registration of territorial behaviour of the lesser spotted eagles in known BT situated in suitable breeding and feeding habitats. The observer checked the surroundings from his/her own position and recorded the time, movement and behaviour of individuals.

In the case that it was not possible to find the nest by June 30 , a check was performed repeatedly with an attempt, on the basis of carrying prey to the young at the nest by adult eagles, to check the occupied nest in the breeding forest.

Third check: from June 28 to July 31 (exceptionally to August 10): During this period direct checks of nests were performed using rope climbing equipment and only by a professionally qualified person, who was authorised for this activity pursuant to the exception provisioned in Act No. 543/2002 Coll. on Nature and Landscape Conservation, as amended, and was the holder of a certificate from training pursuant to $\S 27$ of Act No. 124/2006 Coll. on Occupational Safety and Health Protection. The health status of young birds was checked, along with remains of prey brought to the nest and stability of the nest. In the case of finding an empty nest, the probability of the nest being occupied in the given year was assessed according to signs of occupancy and remnants of prey and a reason for the failure of breeding was given, if appropriate. Measurements and descriptions of the location of the nest were made and biological materials (feathers, unfertilized or abandoned eggs) were collected for the purpose of chemical analyses. In addition, photo documentation and localization of the nest (including other active nests in the breeding territory of the pair) was determined with a GPS device. In exceptional cases of young birds in nests some checks were also performed later, i.e. until August 10. If the nest site of the breeding pair was unknown, it was located on the basis of flying over of eagles with food brought to young in the breeding forest.

Fourth check: from July 25 to September 30: The aim of this check was confirmation of successful or unsuccessful breeding. Confirmation of successful breeding was carried out by photo documentation of the completely feathered young observed in the nest or outside the nest on a branch, young flying together with adult individuals at the nest site, or possibly registering the voice of the young calling from the forest in the vicinity of its eyrie. Confirmation of a successful breeding 
attempt was also made even when young were not found in the nest, but when the amount of white down feathers and traces of droppings suggested that a large completely feathered young bird had vacated the nest. Photo documentation of signs of occupancy confirmed a successful breeding even when the fledged young was not observed in the breeding forest or even at hunting sites with adult individuals throughout the entire period of controlling.

Confirmation of possible failure of breeding was substantiated by photo documentation of deceased young in the nest or on the ground beneath the nest, abandoned or destroyed egg remains found, or deceased young found fledged in the home range of the parental pair.

A record and photo documentation were entered into a prepared form from each of the checks.

Presence of pairs in BT was evaluated in the following categories: 1) confirmed pairs - pairs for which a nest was found at least one time in the evaluated period or the flying of an adult individual with food into the forest was recorded during the breeding period (data localized using a GPS device), 2) probable pairs - pairs for which the pair or an individual was observed one time or more in the evaluated period at a suitable site (data localized using a GPS device).

For comparing the abundance and density of the population of lesser spotted eagles in the individual study areas, data on the abundance of the breeding population given in the National List of Proposed SPAs as of 2003 were used (ŠOP SR, Natura 2000) (http://www.sopsr.sk/natura/index1.php?p=4\&lang=sk\&se $\mathrm{c}=1 \& \mathrm{cpt}=1)$.

Definitions and names of orographic units are according to Mazúr \& Lukniš (1980).

The area of individual SPA as determined by the respective designation of the decree by the Ministry of Environment of the Slovak Republic was used in calculations. In the case of the Slanské vrchy Mts SPA South, the area was calculated from the actual GIS-layers of the existing SPA in the ESRI ArcMap 9.3 environment (Calculate Geometry module). Representation of the habitats in the individual characteristics of the SPA is used according to Rybanič et al. (2004).

During the monitoring we recorded nests found using a GPS device; we measured the height of the nest from the ground, its altitude above the sea level and we determined the species of nest tree. We then ranked nest trees according to 50 and $300 \mathrm{~m}$ altitude scales (m a.s.1.). Nest trees were also assessed with regard to location within the orographic units extending over the territories of the eight SPAs. The measured values related to the height of the nests above ground were evaluated on a height scale of $5 \mathrm{~m}$.

The distribution of pairs of the lesser spotted eagles is recorded in quadrants that are $10 \times 10 \mathrm{~km}$ in size in the network of the European Terrestrial Reference System (ETRS, http://etrs89.ensg.ign.fr/). This network is recommended for a more detailed census for the European Atlas of Bird Distribution and is used in reports on the status of bird species populations for the European Commission in the meaning of the Birds Directive. The territory of Slovakia is divided by this network into 564 quadrants (http://aves.vtaky.sk/sk/about/oatlase).

\section{$\mathrm{D}$ a $\mathrm{t}$ a a $\mathrm{n}$ a $1 \mathrm{y} \mathrm{s}$ is}

We evaluated the effectiveness of the protection zones established around nests for successfully breeding pairs with both found and not found nests, unsuccessfully breeding pairs with a found nest and unproductive pairs with a not found nest, but with statements on the breeding behaviour. Thus, a total of 439 breeding attempts and probable breeding attempts during four breeding seasons, were entered into the analysis. Of them, 81 breeding attempts occurred in the nests without established protection zones. A logistic regression model with a generalized linear model function was used for the analysis. In the analysis we expressed breeding success in binary form. We used the (non)presence of a protection zone around the nest as the explanatory category. We took into consideration the identity of the breeding pair, or the identity of the breeding territory. The program R 3.0.0 (R Development Core Team 2013) was used for the analysis.

\section{Results}

In 2011-2014 a total of 187 breeding territories of the lesser spotted eagles were monitored, covering 1-4 breeding seasons. From the 187 BT monitored the occupied nest of 149 pairs was found at least $1 \times$ (in one of the 4 years of monitoring) and for 21 pairs the nests were not found even $1 \times$ (during the entire project 2011-2014); the remaining 17 BT were not occupied by pairs.

The results of this work are presented in the form of absolute and relative values for the individual SPA and for each year of the monitoring from 2011-2014. The summary numbers for Slovakia presented in the article 
are the summary average values for the individual SPA.

From the 187 breeding territories studied, protection zones were established around the nests of 119 pairs (with a nest found at least one time during the project). In these 119 pairs altogether 314 breeding attempts were secured by established protection zones. In 31 pairs (with a nest found at least one time during the project) no protection zone was established around the nest for a variety of reasons. No protection zone was established for the remaining 20 pairs, because during the project no nest was found and at 17 sites no pairs were even confirmed in at least one year of the project. We compared the breeding success of pairs with protection zones established and that of pairs without protection zones established and subsequently expressed the effectiveness of the established protection zones.

At the end of the monitoring in 2014, the total number of breeding pairs was assessed at 159 . These were distributed in individual SPAs as follows: Laborecká vrchovina Uplands 48, Horná Orava 35, Slanské vrchy Mts 18, Vihorlatské vrchy Mts 17, Volovské vrchy Mts 12, Slovenský kras Mts 12, Nízke Tatry Mts 10 and the Tatry Mts 7.

Of the 159 assessed breeding pairs, 138 were confirmed pairs and 21 were probable pairs. From the stated numbers, 131 confirmed pairs and 20 probable pairs were recorded within the SPAs. Another 7 confirmed pairs and 1 probable pair were found beyond the borders of the SPAs (with the centres of the breeding territories less than $2000 \mathrm{~m}$ from the boundary of the SPAs while home ranges extended into the SPAs). The abundance, density and distribution of the populations for the individual SPA are presented in Tab. 1, Fig. 2-9.
Re productive s u c ces s

In 149 breeding pairs for which the nest was found, a total of 272 successful breeding attempts took place and a total of 277 young (100\%) fledged during 4 breeding seasons: 45 in 2011 (16.25\%), 77 in 2012 $(27.80 \%), 65$ in $2013(23.46 \%)$ and 90 in 2014 $(32.49 \%)$. The average annual values of incorporated BT, present pairs, breeding pairs, successful breeding attempts and number of fledged young come from specific data of the individual SPA (Tab. 2). The highest number of fledged young in all 4 years was found in the Laborecká vrchovina Uplands SPA (101) and the lowest in the Nízke Tatry Mts SPA (13) (Tab. 2). The number of cases of fledging two young from a nest without the human intervention is rare. In 2012 this was $2.67 \%$ and in $20143.45 \%$ of the total number of successful breeding attempts. For all 4 years, from a total of 272 successful breeding attempts, this occurred in 5 cases. Three cases with the fledging of two young from a nest without human intervention were found in the Horná Orava SPA and one case each in the Volovské vrchy Mts SPA and the Slanské vrchy Mts SPA (Tab. 3). The average reproductive success during the monitored period represented from the 277 fledged young/4 years, 512 pairs present/ 4 years, 385 breeding pairs/4 years overall 0.51 juv./pair present, 0.69 juv./breeding pair and 1.37 juv./100 $\mathrm{km}^{2}$ (with the overall area of all eight SPAs, $5562.99 \mathrm{~km}^{2}$ ) (Tab. 4).

\section{Effectiveness of protection} $\mathrm{z}$ o $\mathrm{n}$ e $\mathrm{s}$

Within the LIFE project, within period 2011-2014, a total of 151 protection zones were established around

Tab. 1. Abundance and density of the lesser spotted eagle population (Aquila pomarina) in eight SPAs in Slovakia as of December 31, 2014.

Tab. 1. Početnost' a denzita populácií orla krikl'avého (Aquila pomarina) v ôsmich CHVÚ Slovenska k 31. 12. 2014.

\begin{tabular}{|c|c|c|c|c|c|c|c|c|c|}
\hline \multirow[t]{2}{*}{$\begin{array}{l}\text { SPA / } \\
\text { CHVÚ }\end{array}$} & \multirow{2}{*}{$\begin{array}{l}\begin{array}{l}\text { area / } \\
\text { rozloha }\end{array} \\
\text { km² }^{2}\end{array}$} & \multicolumn{3}{|c|}{$\begin{array}{l}\text { pairs located inside SPA / } \\
\text { páry lokalizované vnútri CHVÚ }\end{array}$} & \multirow{2}{*}{$\begin{array}{l}\begin{array}{l}\text { density / } \\
\text { hustota }\end{array} \\
\text { p/100 km² }\end{array}$} & \multicolumn{3}{|c|}{$\begin{array}{l}\text { pairs located outside SPA (up to } 2 \mathrm{~km} \text { ) / } \\
\text { páry lokalizované mimo CHVÚ (do } 2 \mathrm{~km} \text { ) }\end{array}$} & \multirow{2}{*}{$\begin{array}{l}\overline{2014} \\
\Sigma \Sigma\end{array}$} \\
\hline & & $\begin{array}{l}\text { zistené / } \\
\text { confirmed }\end{array}$ & $\begin{array}{l}\text { predpokladané / } \\
\text { probable }\end{array}$ & $\Sigma$ & & $\begin{array}{l}\text { zistené / } \\
\text { confirmed }\end{array}$ & $\begin{array}{l}\text { predpokladané / } \\
\text { probable }\end{array}$ & $\Sigma$ & \\
\hline Laborecká vrch. & 1028.14 & 47 & 0 & 47 & 4.57 & 1 & & 1 & 48 \\
\hline Horná Orava & 587.38 & 24 & 9 & 33 & 5.62 & 2 & & 2 & 35 \\
\hline Slanské vrchy & 284.00 & 13 & 5 & 18 & 6.34 & & & 0 & 18 \\
\hline Vihorlatské vrchy & 482.86 & 14 & 3 & 17 & 3.53 & & & 0 & 17 \\
\hline Volovské vrchy & 1214.21 & 12 & 0 & 12 & 0.99 & & & 0 & 12 \\
\hline Slovenský kras & 438.60 & 11 & 1 & 12 & 2.74 & & & 0 & 12 \\
\hline Nízke Tatry & 981.69 & 4 & 2 & 6 & 0.61 & 3 & 1 & 4 & 10 \\
\hline Tatry & 546.11 & 6 & 0 & 6 & 1.10 & 1 & & 1 & 7 \\
\hline$\sum$ & 5562.99 & 131 & 20 & 151 & 2.71 & 7 & 1 & 8 & 159 \\
\hline
\end{tabular}



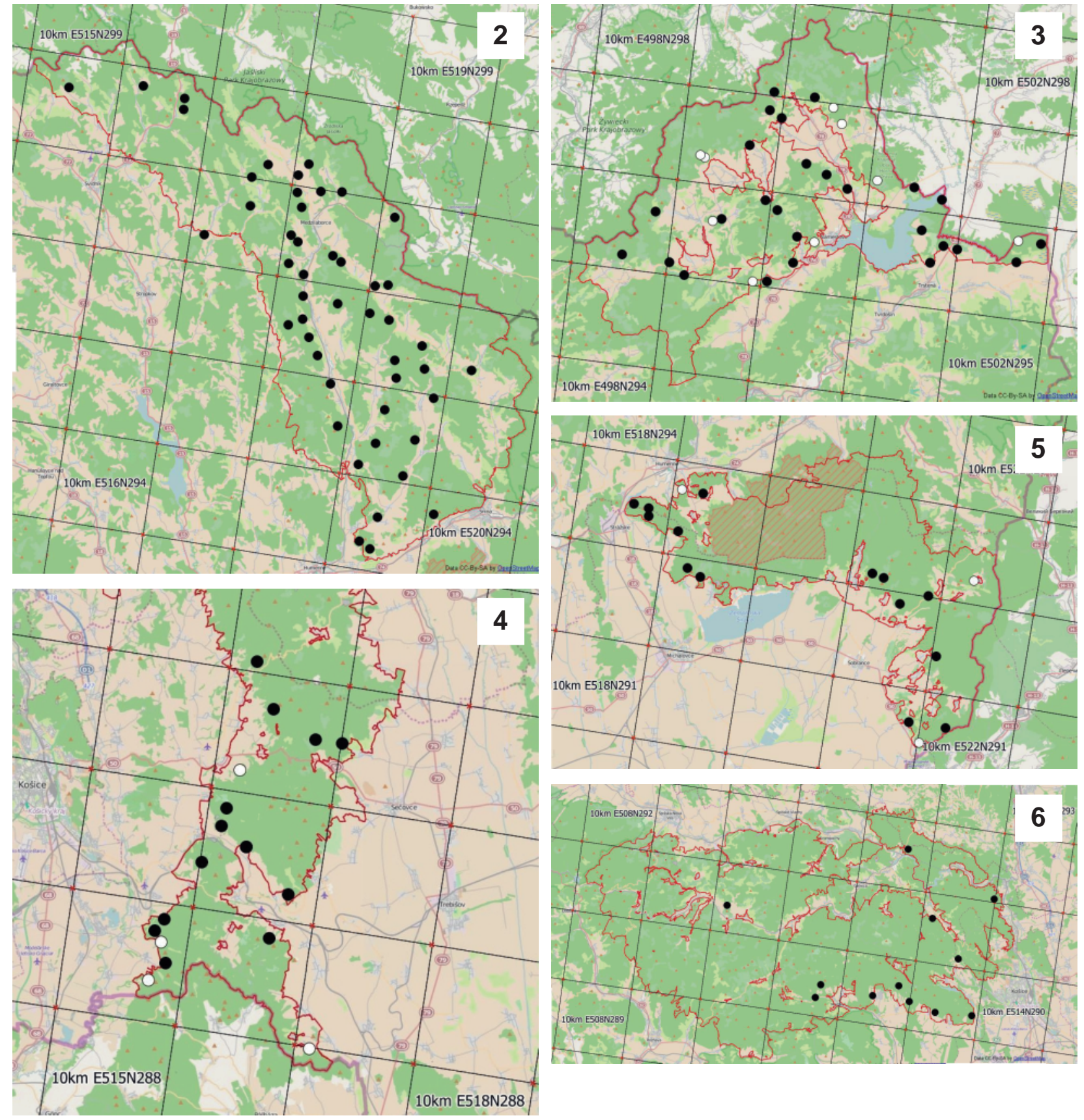

Fig. 2-9. Distribution of the lesser spotted eagle population (Aquila pomarina) in the network of 10x10 km quadrants (European Terrestrial Reference System, ETRS) in the individual SPA as of December 31, 2014. Black circle - confirmed pairs, white circle - probable pairs. The SPA are arranged in descending order according to the abundance of the breeding population: Laborecká vrchovina Uplands (2), Horná Orava (3), Slanské vrchy Mts (4), Vihorlatské vrchy Mts (5), Volovské vrchy Mts (6), Slovenský kras Mts (7), Tatry Mts (8) and Nízke Tatry Mts (9).

Obr. 2 - 9. Distribúcia populácie orla kriklavého (Aquila pomarina) v sieti kvadrátov 10x10 km (European Terrestrial Reference System, ETRS) v jednotlivých CHVú k 31. 12. 2014. Čierny krúžok - zistené páry, biely krúžok - predpokladané páry. CHVú sú zoradené zo-stupne podl'a početnosti hniezdnej populácie: Laborecká vrchovina (2), Horná Orava (3), Slanské vrchy (4), Vihorlatské vrchy (5), Volovské vrchy (6), Slovenský kras (7), Tatry (8) a Nízke Tatry (9). 

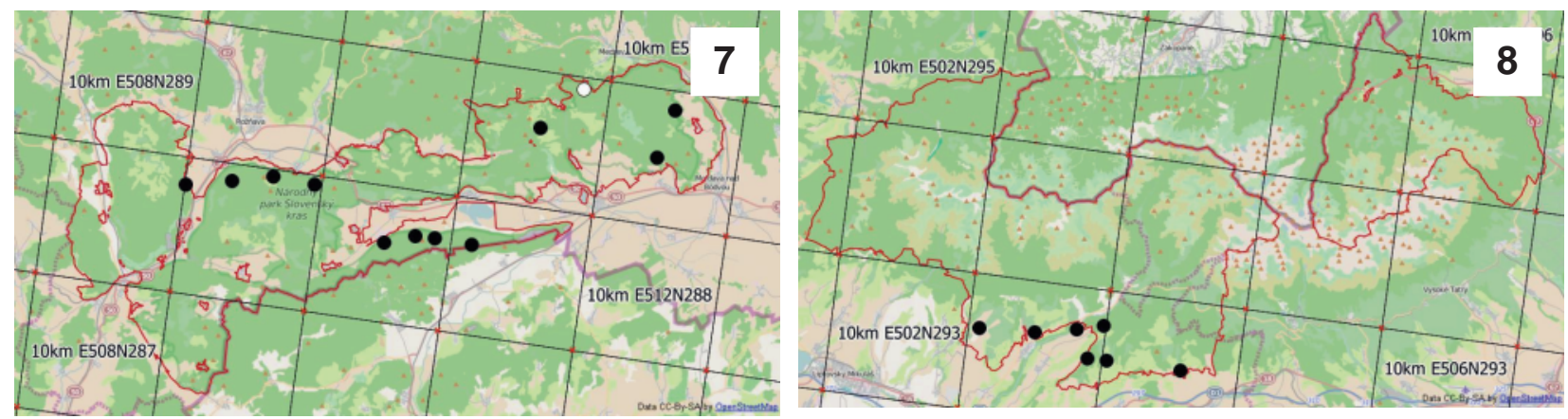

Fig. 2-9. Continuation.

Obr. 2 - 9. Pokračovanie.

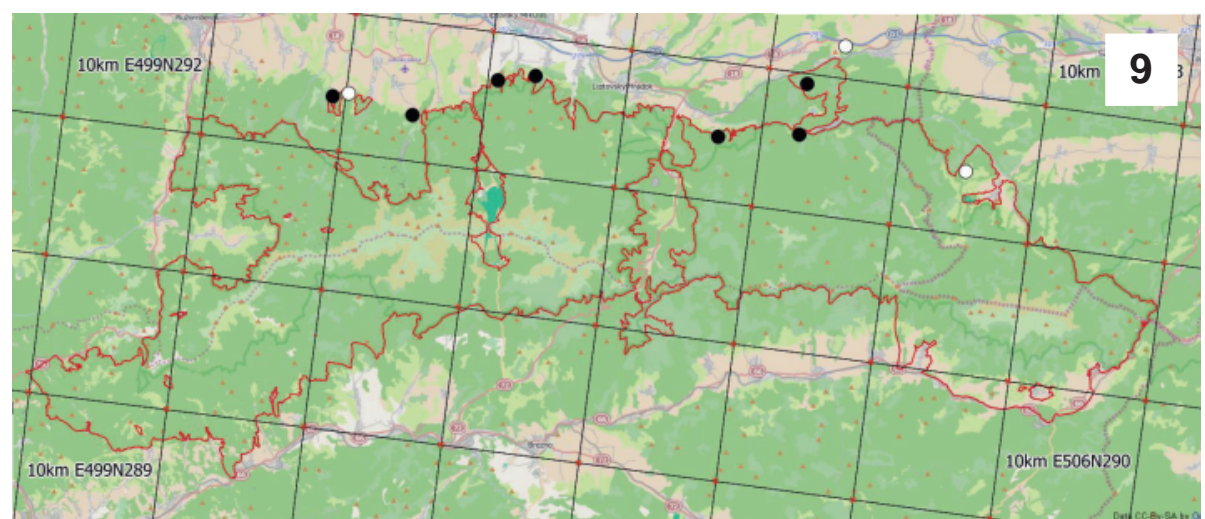

nests of the lesser spotted eagles, which provided protection for 119 breeding territories, representing approximately $17 \%$ of the breeding population of the lesser spotted eagle in Slovakia. During this period a total of 237 young birds fledged.

In this surveyed period, from a total of 439 breeding attempts and probable breeding attempts which were entered into the analysis, 271 were successful. In nests without a protection zone breeding attempts occurred 81 times, 39 of which were successful; in 358 breeding at- tempts with an established protection zone 232 were successful. In nests with an established protection zone the probability of successful raising of young in comparison with nests without such a zone is thus higher $\left(\mathrm{F}_{1,437}=7545, \mathrm{P}<0.01\right)$. The probability that breeding attempts will be successful in the nests of breeding pairs without a protection zone was $48.1 \%$ (95\% confidence intervals (CIs): $37.4-59.0 \%$ ), and in nests with a protection zone it was $64.8 \%$ (95\% CIs: 59.8-69.6\%).

Tab. 2. The number of pairs present, number of breeding pairs, number of successful breeding attempts and the number of fledged young of lesser spotted eagles (Aquila pomarina) in eight SPAs in the years 2011-2014 in Slovakia.

Tab. 2. Počet prítomných párov, počet hniezdiacich párov, počet úspešných hniezdení a počet vyletených mlád’at orlov kriklavých (Aquila pomarina) v ôsmich CHVú v rokoch 2011 - 2014 na Slovensku.

\begin{tabular}{|c|c|c|c|c|c|c|c|c|c|c|c|c|c|c|c|c|c|c|}
\hline \multirow[t]{2}{*}{$\begin{array}{l}\text { SPA / } \\
\text { CHVÚ }\end{array}$} & \multicolumn{3}{|c|}{$\begin{array}{l}\text { present pairs / } \\
\text { prítomné páry }\end{array}$} & \multicolumn{5}{|c|}{$\begin{array}{l}\text { breeding pairs / } \\
\text { hniezdiace páry }\end{array}$} & \multicolumn{5}{|c|}{$\begin{array}{l}\text { succesful breed. attempts / } \\
\text { úspešné hniezdenia }\end{array}$} & \multicolumn{5}{|c|}{$\begin{array}{l}\text { fledged youngs / } \\
\text { vyletené mlád'atá }\end{array}$} \\
\hline & 2011 & 2012 & 2013 & 2014 & 2011 & 2012 & 2013 & 2014 & 2011 & 2012 & 2013 & 2014 & $\sum$ & 2011 & 2012 & 2013 & 2014 & $\Sigma$ \\
\hline Laborecká vrch. & 29 & 33 & 40 & 48 & 24 & 25 & 37 & 37 & 18 & 22 & 25 & 36 & 101 & 18 & 22 & 25 & 36 & 101 \\
\hline Horná Orava & 31 & 29 & 31 & 28 & 19 & 20 & 25 & 20 & 9 & 16 & 16 & 11 & 52 & 9 & 18 & 16 & 12 & 55 \\
\hline Vihorlatské vrchy & 8 & 12 & 7 & 17 & 4 & 8 & 7 & 14 & 2 & 8 & 5 & 11 & 26 & 2 & 8 & 5 & 11 & 26 \\
\hline Slanské vrchy & 12 & 18 & 12 & 11 & 10 & 10 & 6 & 8 & 4 & 9 & 5 & 6 & 24 & 4 & 9 & 5 & 7 & 25 \\
\hline Volovské vrchy & 9 & 11 & 11 & 12 & 7 & 8 & 7 & 11 & 3 & 7 & 2 & 8 & 20 & 3 & 7 & 2 & 9 & 21 \\
\hline Slovenský kras & 10 & 10 & 10 & 11 & 7 & 9 & 9 & 10 & 5 & 4 & 4 & 7 & 20 & 5 & 4 & 4 & 7 & 20 \\
\hline Tatry & 6 & 7 & 7 & 7 & 2 & 7 & 4 & 7 & 1 & 7 & 4 & 4 & 16 & 1 & 7 & 4 & 4 & 16 \\
\hline Nízke Tatry & 11 & 8 & 8 & 8 & 7 & 6 & 5 & 5 & 3 & 2 & 4 & 4 & 13 & 3 & 2 & 4 & 4 & 13 \\
\hline$\sum$ & 116 & 128 & 126 & 142 & 80 & 93 & 100 & 112 & 45 & 75 & 65 & 87 & 272 & 45 & 77 & 65 & 90 & 277 \\
\hline
\end{tabular}


Tab. 3. Frequency of the number young lesser spotted eagles (Aquila pomarina) fledged in eight SPAs in the years 2011-2014 in Slovakia.

Tab. 3. Frekvencia počtu vyvedených mlád'at orlov kriklavých (Aquila pomarina) v ôsmich CHVú v rokoch 2011 - 2014 na Slovensku.

\begin{tabular}{|c|c|c|c|c|c|c|}
\hline \multirow[t]{2}{*}{$\begin{array}{l}\text { SPA/ } \\
\text { CHVÚ }\end{array}$} & \multicolumn{6}{|c|}{$\begin{array}{l}\text { distributionion of number fledged youngs / } \\
\text { frekvencia počtu vyvedených mlád'at }\end{array}$} \\
\hline & 2011 & 2012 & 2013 & 2014 & $\Sigma$ & $\Sigma$ \\
\hline Laborecká vrch. & $18 \times 1$ & $22 \times 1$ & $25 \times 1$ & $36 \times 1$ & $101 \times 1$ & 101 \\
\hline Horná Orava & $9 \times 1$ & $14 \times 1,2 \times 2$ & $16 \times 1$ & $10 \times 1,1 \times 2$ & $49 \times 1,3 \times 2$ & 55 \\
\hline Vihorlatské vrchy & $2 \times 1$ & $8 \times 1$ & $5 \times 1$ & $11 \times 1$ & $26 \times 1$ & 26 \\
\hline Slanské vrchy & $4 \times 1$ & $9 \times 1$ & $5 \times 1$ & $5 \times 1,1 \times 2$ & $23 \times 1,1 \times 2$ & 25 \\
\hline Volovské vrchy & $3 \times 1$ & $7 \times 1$ & $2 \times 1$ & $7 \times 1,1 \times 2$ & $19 \times 1,1 \times 2$ & 21 \\
\hline Slovenský kras & $5 \times 1$ & $4 \times 1$ & $4 \times 1$ & $7 \times 1$ & $20 \times 1$ & 20 \\
\hline Tatry & $1 \times 1$ & $7 \times 1$ & $4 \times 1$ & $4 \times 1$ & $16 \times 1$ & 16 \\
\hline Nízke Tatry & $3 \times 1$ & $2 \times 1$ & $4 \times 1$ & $4 \times 1$ & $13 \times 1$ & 13 \\
\hline$\sum$ & $45 \times 1$ & $73 \times 1,2 \times 2$ & $65 \times 1$ & $84 \times 1,3 \times 2$ & $267 \times 1,5 \times 2$ & \\
\hline$\sum$ & 45 & 77 & 65 & 90 & 277 & 277 \\
\hline
\end{tabular}

Tab. 4. Reproduction success of lesser spotted eagles (Aquila pomarina) expressed individually in eight SPAs in the years 2011-2014 and average (av) for Slovakia.

Tab. 4. Reprodukčná úspešnost' orlov kriklavých (Aquila pomarina) vyjadrená jednotlivo v ôsmich CHVÚ v rokoch $2011-2014$ a priemerne (av) pre Slovensko.

\begin{tabular}{|c|c|c|c|c|c|c|c|c|c|c|c|c|c|c|c|}
\hline \multirow[t]{2}{*}{$\begin{array}{l}\text { SPA / } \\
\text { CHVÚ }\end{array}$} & \multicolumn{5}{|c|}{$\begin{array}{l}\text { juv./pair present / } \\
\text { juv./prítomný pár }\end{array}$} & \multicolumn{5}{|c|}{$\begin{array}{l}\text { juv./pair breeding / } \\
\text { juv./hniezdiaci pár }\end{array}$} & \multicolumn{5}{|c|}{$\begin{array}{l}\text { juv./100 km²/ } \\
\text { juv./100 km }{ }^{2}\end{array}$} \\
\hline & 2011 & 2012 & 2013 & 2014 & av & 2011 & 2012 & 2013 & 2014 & av & 2011 & 2012 & 2013 & 2014 & av \\
\hline Laborecká vrchovina & 0.62 & 0.67 & 0.63 & 0.75 & 0.67 & 0.75 & 0.88 & 0.68 & 0.97 & 0.82 & 1.75 & 2.14 & 2.43 & 3.50 & 2.46 \\
\hline Horná Orava & 0.29 & 0.62 & 0.52 & 0.43 & 0.47 & 0.47 & 0.90 & 0.64 & 0.60 & 0.65 & 1.53 & 3.06 & 2.72 & 2.04 & 2.34 \\
\hline Slanské vrchy & 0.33 & 0.50 & 0.42 & 0.64 & 0.47 & 0.40 & 0.90 & 0.83 & 0.88 & 0.75 & 1.41 & 3.17 & 1.76 & 2.46 & 2.20 \\
\hline Vihorlatské vrchy & 0.25 & 0.67 & 0.71 & 0.65 & 0.57 & 0.50 & 1.00 & 0.71 & 0.79 & 0.75 & 0.41 & 1.66 & 1.04 & 2.28 & 1.35 \\
\hline Slovenský kras & 0.50 & 0.40 & 0.40 & 0.64 & 0.49 & 0.71 & 0.44 & 0.44 & 0.70 & 0.57 & 1.14 & 0.91 & 0.91 & 1.60 & 1.14 \\
\hline Tatry & 0.17 & 1.00 & 0.57 & 0.57 & 0.58 & 0.50 & 1.00 & 1.00 & 0.57 & 0.77 & 0.18 & 1.28 & 0.73 & 0.73 & 0.73 \\
\hline Volovské vrchy & 0.33 & 0.64 & 0.18 & 0.75 & 0.48 & 0.43 & 0.88 & 0.29 & 0.82 & 0.61 & 0.25 & 0.58 & 0.16 & 0.74 & 0.43 \\
\hline Nízke Tatry & 0.27 & 0.25 & 0.50 & 0.50 & 0.38 & 0.43 & 0.33 & 0.80 & 0.80 & 0.59 & 0.31 & 0.20 & 0.41 & 0.41 & 0.33 \\
\hline$\sum$ & 0.35 & 0.59 & 0.49 & 0.62 & 0.51 & 0.52 & 0.79 & 0.67 & 0.77 & 0.69 & 0.87 & 1.63 & 1.27 & 1.72 & 1.37 \\
\hline
\end{tabular}

$\mathrm{N}$ e s t $\mathrm{t}$ r e e $\mathrm{s}$

In the course of 4 breeding seasons, 141 breeding pairs used nests located in 215 trees of 18 different species. From the stated number of BP, 81 used only one nest, 47 pairs used two, 12 pairs used three and one pair successfully used 4 nests (each year it built a new nest and successfully raised one young bird in it). Among the 5 most commonly used nest trees in Slovakia were Picea abies $61 \times(28.37 \%)$, Pinus sylvestris $45 \times(20.93 \%)$, Quercus sp. $36 \times(16.74 \%)$, Fagus sylvatica $25 \times$ $(11.62 \%)$ and Abies alba $18 \times(8.37 \%)$. Among the more rarely used species were Larix decidua $12 \times(5.57 \%)$ and Alnus glutinosa $3 \times(1.39 \%)$. Eagles used an additional 11 species of trees only rarely or exceptionally, which did not achieve even $1 \%$ of the total (Tab. 5). Differences in the selection and use of nest trees were found in eagles of the individual SPA. The highest variability of tree species used was recorded in SPA Laborecká vrchovina Uplands (12 species, $\mathrm{n}=70)$ with Pinus sylvestris 34 (48.57\%), Fagus sylvatica 13 (18.57\%) and Larix decidua 8 (11.42\%) showing dominant representation, and the lowest in SPA Horná Orava (3 species, $\mathrm{n}=48$ ) with Picea abies $41(85.42 \%)$ pre-
Tab. 5. A summary overview of the numbers of confirmed nest tree species of the lesser spotted eagle (Aquila pomarina) in Slovakia (expressed by the sum of nest trees confirmed in eight SPAs in 2011-2014) $(n=215)$.

Tab. 5. Sumárny prehl'ad počtov zistených druhov hniezdnych stromov orlov kriklavých (Aquila pomarina) na Slovensku (vyjadrený súčtom hniezdnych stromov zistených v ôsmich CHVÚ v rokoch $2011-2014)(n=215)$.

\begin{tabular}{llrr}
\hline No. I & nest tree species / & n & \% \\
P.č. & druh hniezdneho stromu & 61 & 28.37 \\
\hline 1. & Picea abies & 45 & 20.93 \\
2. & Pinus sylvestris & 36 & 16.74 \\
3. & Quercus sp. & 25 & 11.62 \\
4. & Fagus sylvatica & 18 & 8.37 \\
5. & Abies alba & 12 & 5.57 \\
6. & Larix decidua & 3 & 1.39 \\
7. & Alnus glutinosa & 2 & 0.93 \\
8. & Pinus nigra & 2 & 0.93 \\
9. & Cerasus avium & 2 & 0.93 \\
10. & Carpinus betulus & 2 & 0.93 \\
11. & Pyrus pyraster & 1 & 0.47 \\
12. & Betula pendula & 1 & 0.47 \\
13. & Quercus robur & 1 & 0.47 \\
14. & Acer pseudoplatanus & 1 & 0.47 \\
15. & Populus tremula & 1 & 0.47 \\
16. & Tilia cordata & 1 & 0.47 \\
17. & Tilia sp. & 1 & 0.47 \\
18. & Fraxinus excelsior & $\mathbf{2 1 5}$ & $\mathbf{1 0 0 . 0 0}$ \\
\hline$\Sigma$ & & &
\end{tabular}


Tab. 6. An overview of the numbers of species of nest trees $(n=215)$ found in eight SPAs in Slovakia and in the orographic units corresponding to the respective SPA.

Tab. 6. Prehlad počtov zistených druhov hniezdnych stromov $(n=215)$ v ôsmich CHVú na Slovensku a v orografických celkoch zodpovedajúcich predmetným CHVú.

\begin{tabular}{|c|c|c|c|c|c|c|c|c|}
\hline $\begin{array}{l}\text { SPA / } \\
\text { CHVÚ }\end{array}$ & $\begin{array}{l}\text { No. of } \\
\text { pairs / } \\
\text { počet } \\
\text { párov }\end{array}$ & $\begin{array}{l}\text { No. of } \\
\text { nests / } \\
\text { počet } \\
\text { hniezd }\end{array}$ & $\begin{array}{l}\text { No. of } \\
\text { species / } \\
\text { počet } \\
\text { druhov }\end{array}$ & $\begin{array}{l}\text { orographic unit / } \\
\text { orografický celok }\end{array}$ & $\begin{array}{l}\text { No. of } \\
\text { nests / } \\
\text { počet } \\
\text { hniezd }\end{array}$ & $\begin{array}{l}\text { No. of } \\
\text { species / } \\
\text { počet } \\
\text { druhov }\end{array}$ & $\begin{array}{l}\text { nest tree } \\
\text { species / } \\
\text { druh hniezdneho } \\
\text { stromu }\end{array}$ & $\mathbf{n}$ \\
\hline Laborecká & 44 & 70 & 12 & Laborecká vrchovina & 66 & 11 & Pinus sylvestris & 31 \\
\hline vrchovina & & & & & & & Fagus sylvatica & 13 \\
\hline \multirow{11}{*}{ Uplands } & & & & & & & Larix decidua & 8 \\
\hline & & & & & & & Abies alba & 4 \\
\hline & & & & & & & Cerasus avium & 2 \\
\hline & & & & & & & Pyrus pyraster & 2 \\
\hline & & & & & & & Picea abies & 2 \\
\hline & & & & & & & Quercus robur & 1 \\
\hline & & & & & & & Carpinus betulus & 1 \\
\hline & & & & & & & Acer pseudoplatanus & 1 \\
\hline & & & & & & & Populus tremula & 1 \\
\hline & & & & Ondavská vrchovina & 4 & 2 & Pinus sylvestris & 3 \\
\hline & & & & & & & Betula pendula & 1 \\
\hline Horná & 31 & 48 & 3 & Oravská kotlina & 18 & 2 & Picea abies & 16 \\
\hline \multirow[t]{6}{*}{ Orava } & & & & & & & Pinus sylvestris & 2 \\
\hline & & & & Podbeskydská vrchovina & 18 & 2 & Picea abies & 13 \\
\hline & & & & & & & Abies alba & 5 \\
\hline & & & & Oravské Beskydy & 7 & 1 & Picea abies & 7 \\
\hline & & & & Podbeskydská brázda & 3 & 1 & Picea abies & 3 \\
\hline & & & & Oravská Magura & 2 & 1 & Picea abies & 2 \\
\hline \multirow{5}{*}{$\begin{array}{l}\text { Slanské } \\
\text { vrchy Mts }\end{array}$} & 19 & 27 & 4 & Slanské vrchy & 25 & 4 & Quercus sp. & 21 \\
\hline & & & & & & & Fagus sylvatica & 2 \\
\hline & & & & & & & Alnus glutinosa & 1 \\
\hline & & & & & & & Tilia cordata & 1 \\
\hline & & & & Východosl. pahorkatina & 2 & 1 & Quercus sp. & 2 \\
\hline \multirow{10}{*}{$\begin{array}{l}\text { Volovské } \\
\text { vrchy Mts }\end{array}$} & 12 & 18 & 6 & Košická kotlina & 8 & 5 & Pinus sylvestris & 3 \\
\hline & & & & & & & Abies alba & 2 \\
\hline & & & & & & & Alnus glutinosa & 1 \\
\hline & & & & & & & Fagus sylvatica & 1 \\
\hline & & & & & & & Quercus sp. & 1 \\
\hline & & & & Volovské vrchy & 8 & 4 & Abies alba & 3 \\
\hline & & & & & & & Pinus sylvestris & 2 \\
\hline & & & & & & & Larix decidua & 2 \\
\hline & & & & & & & Alnus glutinosa & 1 \\
\hline & & & & Čierna hora & 2 & 1 & Abies alba & 2 \\
\hline \multirow{7}{*}{$\begin{array}{l}\text { Slovenský } \\
\text { kras Mts }\end{array}$} & 10 & 15 & 6 & Slovenský kras & 13 & 6 & Quercus sp. & 6 \\
\hline & & & & & & & Pinus nigra & 2 \\
\hline & & & & & & & Fagus sylvatica & 2 \\
\hline & & & & & & & Pinus sylvestris & 1 \\
\hline & & & & & & & Tilia sp. & 1 \\
\hline & & & & & & & Fraxinus excelsior & 1 \\
\hline & & & & Rožňavská kotlina & 2 & 1 & Fagus sylvatica & 2 \\
\hline \multirow{6}{*}{$\begin{array}{l}\text { Vihorlatské } \\
\text { vrchy Mts }\end{array}$} & 12 & 14 & 4 & Vihorlatské vrchy & 11 & 4 & Fagus sylvatica & 4 \\
\hline & & & & & & & Quercus sp. & 4 \\
\hline & & & & & & & Pinus sylvestris & 2 \\
\hline & & & & & & & Carpinus betulus & 1 \\
\hline & & & & Východos. pahorkatina & 3 & 2 & Quercus sp. & 2 \\
\hline & & & & & & & Fagus sylvatica & 1 \\
\hline
\end{tabular}


Tab. 6. Continuation.

Tab. 6. Pokračovanie.

\begin{tabular}{|c|c|c|c|c|c|c|c|c|}
\hline \multirow[t]{2}{*}{$\begin{array}{l}\text { SPA / } \\
\text { CHVÚ }\end{array}$} & \multirow[b]{2}{*}{$\begin{array}{l}\text { No. of } \\
\text { pairs / } \\
\text { počet } \\
\text { párov }\end{array}$} & \multirow[b]{2}{*}{$\begin{array}{l}\text { No. of } \\
\text { nests / } \\
\text { počet } \\
\text { hniezd }\end{array}$} & \multirow[b]{2}{*}{$\begin{array}{l}\text { No. of } \\
\text { species / } \\
\text { počet } \\
\text { druhov }\end{array}$} & \multirow[t]{2}{*}{$\begin{array}{l}\text { orographic unit / } \\
\text { orografický celok }\end{array}$} & \multirow[b]{2}{*}{$\begin{array}{l}\text { No. of } \\
\text { nests / } \\
\text { počet } \\
\text { hniezd }\end{array}$} & \multirow[b]{2}{*}{$\begin{array}{l}\text { No. of } \\
\text { species / } \\
\text { počet } \\
\text { druhov }\end{array}$} & \multirow[b]{2}{*}{$\begin{array}{l}\text { nest tree } \\
\text { species / } \\
\text { druh hniezdneho } \\
\text { stromu }\end{array}$} & \multirow[b]{2}{*}{$\mathbf{n}$} \\
\hline & & & & & & & & \\
\hline Nízke & 7 & 12 & 4 & Ďumbierske Tatry & 5 & 2 & Picea abies & 4 \\
\hline \multirow[t]{6}{*}{ Tatry Mts } & & & & & & & Abies alba & 1 \\
\hline & & & & Liptovská kotlina & 4 & 2 & Picea abies & 3 \\
\hline & & & & & & & Larix decidua & 1 \\
\hline & & & & Kozie chrbty & 2 & 2 & Picea abies & 1 \\
\hline & & & & & & & Pinus sylvestris & 1 \\
\hline & & & & Král'ovohol'ské Tatry & 1 & 1 & Larix decidua & 1 \\
\hline \multirow[t]{2}{*}{ Tatry Mts } & 6 & 11 & 2 & Liptovská kotlina & 11 & 2 & Picea abies & 10 \\
\hline & & & & & & & Abies alba & 1 \\
\hline $\bar{\Sigma}$ & 141 & 215 & 18 & & 215 & 18 & & 215 \\
\hline
\end{tabular}

dominating, followed by Abies alba $5(10.42 \%)$ and in SPA Tatry Mts (2 species, $\mathrm{n}=11)$ Picea abies 10 (90.91\%) and Abies alba 1 (9.09\%). The abundance and variability of nest trees in the individual SPA are presented in Tab. 6 .

The highest variability of nest trees of $A$. pomarina in terms of the orographic units sprawling over the eight SPAs was found in the Laborecká vrchovina Uplands with 11 species, Slovenský kras Mts with 6, Košická kotlina Basin with 5, and the Volovské vrchy Mts, Vihorlatské vrchy Mts and Slanské vrchy Mts with 4 species each. All of the mentioned orographic units are located in eastern Slovakia. The variability of nest trees determined in central Slovakia was much lower: in the Liptovská kotlina Basin 3, Oravská kotlina Basin 2, Podbeskydská vrchovina Uplands 2, Oravské Beskydy Mts 1, Oravská Magura Mts 1, Podbeskydská brázda Gap 1, Dumbierské Tatry Mts 2 and the Král'ovohol'ské Tatry Mts 1 . The location of nests only in spruce (Picea abies) was found in the orographic unit Oravská Magura Mts, Podbeskydská brázda Gap and Oravské Beskydy Mts, and with more than $70 \%$ representation in the orographic units Podbeskydská vrchovina Uplands, Ďumbierské Tatry Mts, Liptovská kotlina Basin and Oravská kotlina Basin (Tab. 6).

A $1 \mathrm{titude}$ of $\mathrm{nest} \mathrm{trees}$

During analysis of 215 located nests of $A$. pomarina with the use of a $50 \mathrm{~m}$ height scale, the highest number of nest trees was found in the range of $401-450 \mathrm{~m}$ a.s.l., namely 34 nests $(15.81 \%)$; in the interval from $351-400 \mathrm{~m}$ a.s.1. 29 nests $(13.49 \%)$ were found. Other altitude zones were at levels below $10 \%$ (Fig. 10). On the basis of these results we can state that more than $50 \%$ of confirmed nests (specifically 116 nests, $53.95 \%$ ) are located in the altitude zone $301-600 \mathrm{~m}$ a.s.l. The second highest number of nests was found in the altitude zone 600-900 $\mathrm{m}$ a.s.1. (71 nests, $33.02 \%$ ). Only 23 nests were found in the lowest $300 \mathrm{~m}$ zone $001-300 \mathrm{~m}$ a.s.1. (10.70\%), while only 5 nests $(2.33 \%)$ were found in the highest zone 901-1200 $\mathrm{m}$ a.s.l. (Fig. 11). The lowest situated nest was at an altitude of $150 \mathrm{~m}$ and the highest at $950 \mathrm{~m}$ a.s.l. The overall average altitude of nests found in the eight SPAs is $595.01 \mathrm{~m}$ a.s.1. $(\mathrm{n}=215)$. The highest average altitude of the nests in the eight SPAs was found in SPA Tatry Mts -

Tab. 7. The average altitude of the nest trees of lesser spotted eagles (Aquila pomarina) determined $(n=215)$ in eight SPAs in Slovakia. The arrangement of the SPAs is in descending order.

Tab. 7. Priemerné nadmorské výšky zistených hniezdnych stromov $(n=215)$ orlov kriklavých (Aquila pomarina) v ôsmich CHVÚ na Slovensku. Zoradenie CHVÚ v zostupnom poradí.

\begin{tabular}{lclll}
\hline SPA / & $\begin{array}{c}\text { No. of nests / } \\
\text { počet hniezd } \\
\text { CHVÚ }\end{array}$ & $\begin{array}{l}\text { altitude (m a. s. I) / } \\
\text { nadm. výška (m n. m.) } \\
\text { mean / }\end{array}$ & $\begin{array}{l}\text { min. } \\
\text { priemer }\end{array}$ & max. \\
\hline Tatry & 11 & 836.54 & 762 & 897 \\
Nízke Tatry & 12 & 793.75 & 698 & 944 \\
Horná Orava & 48 & 749.00 & 603 & 950 \\
Slovenský kras & 15 & 483.93 & 371 & 638 \\
Volovské vrchy & 18 & 474.44 & 352 & 693 \\
Laborecká vrch. & 70 & 409.27 & 231 & 575 \\
Slanské vrchy & 27 & 393.11 & 230 & 542 \\
Vihorlatské vrchy & 14 & 329.57 & 150 & 530 \\
\hline$\sum$ & $\mathbf{2 1 5}$ & $\mathbf{5 5 8 . 7 0}$ & $\mathbf{1 5 0}$ & $\mathbf{9 5 0}$ \\
\hline
\end{tabular}



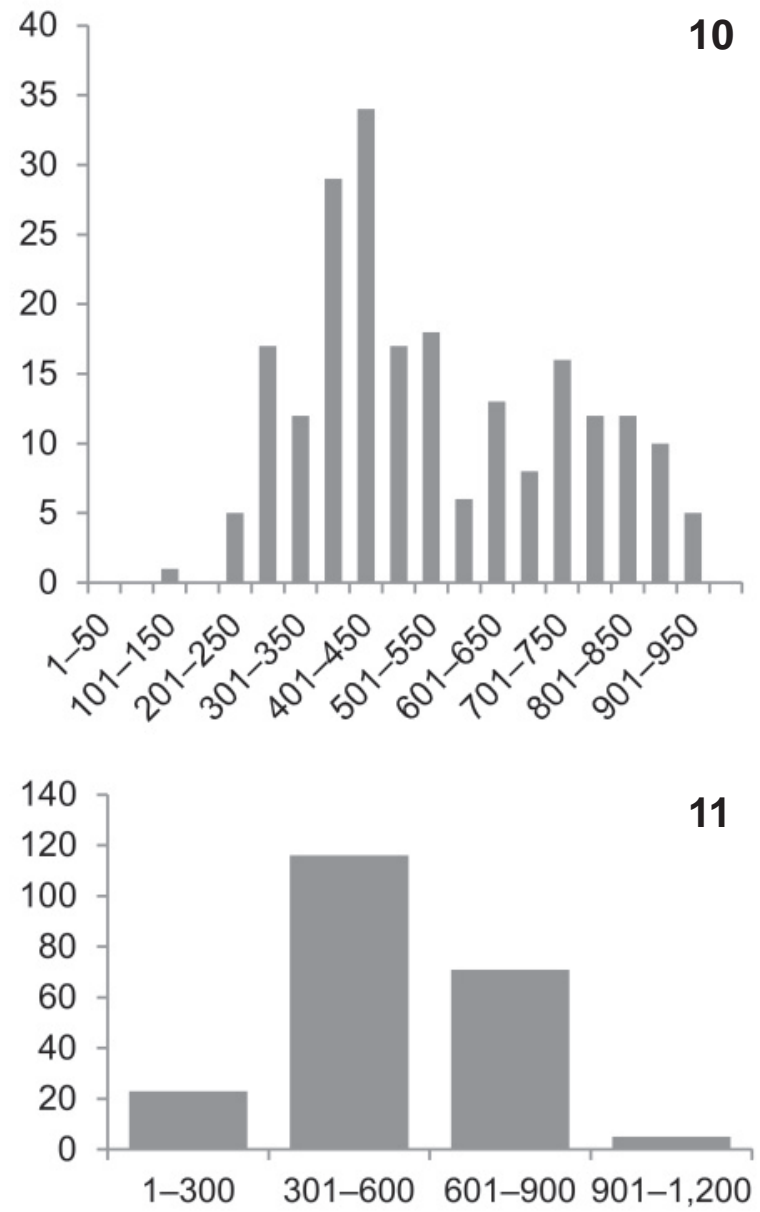

Fig. 10-11. Hypsographic divisions of nest trees of the lesser spotted eagle (Aquila pomarina) in Slovakia (found in eight SPAs in 2011-2014) $(n=215)$ according to altitude at intervals of $50 \mathrm{~m} \mathrm{(10)}$ and $300 \mathrm{~m}$ (11).

Obr. 10 - 11. Hypsografické rozdelenie hniezdnych stromov orla kriklavého (Aquila pomarina) na Slovensku ( zistených v ôsmich CHVÚ $v$ rokoch 2011 - 2014) ( $n=215)$ podla nadmorskej výšky vo výškových intervaloch 50 m (10) a 300 m (11).

$836.54 \mathrm{~m}(\mathrm{n}=11,762-897 \mathrm{~m}$ a.s.1. $)$ and the lowest in SPA Vihorlatské vrchy Mts -329.57 ( $\mathrm{n}=14,150-530 \mathrm{~m}$ a.s.1.) (Tab. 7). The highest found nests with regard to altitude and orographic unit for Aquila pomarina in the eight SPAs were found in the orographic unit Podbeskydská brázda Gap with an average altitude of $912 \mathrm{~m}$ a.s.l. $(\mathrm{n}=3$, 893-942 $\mathrm{m}$ a.s.1.) and the lowest in the orographic unit Východoslovenská pahorkatina Uplands at $244.60 \mathrm{~m}$ a.s.1. $(\mathrm{n}=5,150-340 \mathrm{~m}$ a.s.1.). The altitude of nests in other orographic units is shown in Appendix 1.

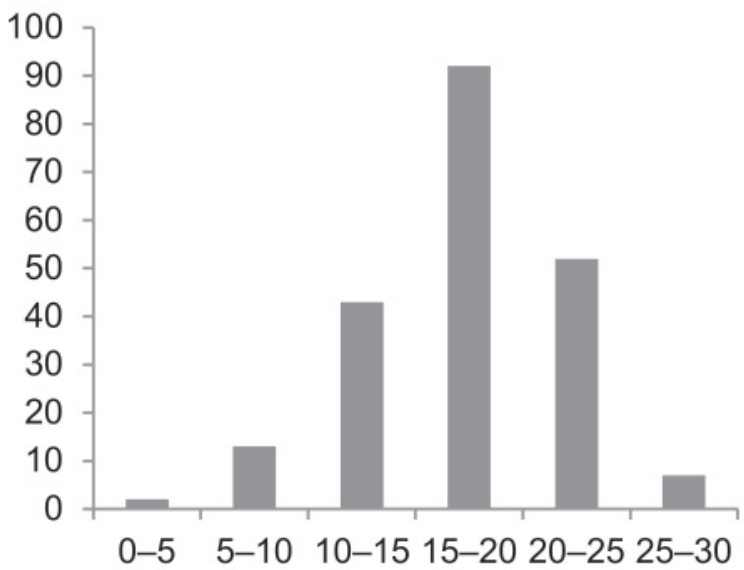

Fig 12. Height divisions of nest locations above ground of the lesser spotted eagle (Aquila pomarina) in Slovakia (found in eight SPAs in 2011-2014) $(n=209)$ in a height scale of $5 \mathrm{~m}$.

Obr. 12. Výškové rozdelenie umiestnenia hniezd nad zemou orla kriklavého (Aquila pomarina) na Slovensku (zistených $v$ ôsmich CHVú v rokoch 2011 - 2014) (n = 209) vo výškovej škále $5 \mathrm{~m}$.

P la cement of nest a b ove g r o u n d

From the total number of analyzed nests $(n=215)$ the heights of the nests above ground were measured in 209 cases. The highest number of nests was found on the height scale of $5 \mathrm{~m}$ in the range from $15.1-20.0 \mathrm{~m}$ above ground ( $\mathrm{n}=92,44.02 \%$ ) (Fig. 12). The lowest nest was found at a height of $5 \mathrm{~m}$ and the highest at $30 \mathrm{~m}$ above ground.

\section{Discussion}

According to Bergmanis et al. (2015) the core portion of the population of the species in its distribution grounds is located in the countries with the highest number of pairs: Latvia (3,800 pairs), Belarus (3,200-3,800 pairs), Lithuania (1,900-2,900 pairs), Estonia (600-700 pairs) and Poland (2,283-2,739 pairs).

Although Estonia at present has shown the stability of its population (Väli 2015), several core countries have confirmed a decreasing trend in population. Bergmanis et al. (2015) recorded a decline in Latvia in 2003-2011 and Treinys et al. (2007) a 26\% decline in Lithuania in 1980-2006. More significantly, however, a $23 \%$ decline was recorded on the western boundary of the species distribution in Germany (Meyburg et al. 2008). In the Czech Republic in 2001-2003 no breeding pairs were recorded, and the species was considered to 
be regionally extinct (Štastný \& Bejček 2003, Štastný et al. 2003). In 2010-2013 again only one breeding pair was recorded in the Czech Republic (Bělka 2014). In Slovakia from 2000-2013 a 23\% decline in the breeding population was recorded (Dravecký et al. 2015). Even more significant was the up to $50 \%$ drop recorded in neighbouring Hungary (Pongrácz \& Szitta 2015).

In populations situated on the edge of the species distribution range a lower abundance was recorded as well as a lower density. In Slovakia an average population density of $2.71 \mathrm{bp} / 100 \mathrm{~km}^{2}$ was determined from the average population density in the eight SPAs (0.61-6.34 bp/100 km², Tab. 1). The determined value corresponds to the overall average density of the population as of 2014 , i.e. $2.1-2.8$ breeding pairs $/ 100 \mathrm{~km}^{2}$, when the breeding territory of the lesser spotted eagle in Slovakia spread over an area of approximately 28,935 $\mathrm{km}^{2}$ and the abundance of the breeding population was estimated at $600-800$ pairs. At the same time the range of densities in the eight SPAs $\left(0.61-6.34 \mathrm{bp} / 100 \mathrm{~km}^{2}\right.$, Tab. 1) corresponds to the density of the breeding population of the lesser spotted eagle in the mapped units (districts) in Slovakia as of 1997 (0.07-5.29 pairs/100 $\mathrm{km}^{2}$ ). A higher density in 1997 was recorded only in the districts of Dolný Kubín (7.05) and Stará Lubovňa (8.01 pairs/100 km²) (Dravecký et al. 2015).

The overall density of the breeding population in Slovakia as well as the density of populations in the individual SPAs which are presented in this work is much lower in comparison with the populations densities found in Latvia. For example, at the Žuklis location in the $2002 / 2003$ season $32-33$ pairs $/ 100 \mathrm{~km}^{2}$ were found, which fell in 2005-2014 to $21.3-26.6$ pairs $/ 100 \mathrm{~km}^{2}$, or at the Mazgramzda location (checked since 2008, 12-18 pairs $/ 100 \mathrm{~km}^{2}$ ) (Bergmanis et al. 2015). High densities were also found in Belarus (7.5-10.9 pairs $\left./ 100 \mathrm{~km}^{2}\right)$, locally even up to 20 pairs $/ 100 \mathrm{~km}^{2}$ (Dombrovski \& Ivanovski 2005), and in Poland (more than 10 pairs/100 $\mathrm{km}^{2}$ ), but likewise with an average density of 1-5 pairs $/ 100 \mathrm{~km}^{2}$ (Mirski et al. 2013). The densities determined in Poland are comparable with the overall density of the breeding population in Slovakia and the densities of the populations in the eight SPAs presented in this work. A lower density was found in north-eastern Germany, in the state of Mecklenburg - Pomerania, with 1.4 pairs $/ 100 \mathrm{~km}^{2}$ (Scheller et al. 2001).

The densities of the breeding population has been divided into the following classes (Bergmanis et al. 2015): (1) extra high: $15-24.5 \mathrm{p} / 100 \mathrm{~km}^{2}$, (2) high:
8-11 p/100 km², (3) moderate: $3.9-4.7 \mathrm{p} / 100 \mathrm{~km}^{2}$, (4) medium: $3.3-3.7 \mathrm{p} / 100 \mathrm{~km}^{2}$, and (5) low: $1.5 \mathrm{p} / 100$ $\mathrm{km}^{2}$. According to this classification only SPA Horná Orava $\left(5.64 \mathrm{p} / 100 \mathrm{~km}^{2}\right)$ and Slanské vrchy Mts (South) $\left(6.34 \mathrm{p} / 100 \mathrm{~km}^{2}\right)$ would belong to the classes with a moderate to high density, SPA Laborecká vrchovina Uplands $\left(4.57 \mathrm{p} / 100 \mathrm{~km}^{2}\right)$ to the class with moderate density, SPA Vihorlatské vrchy Mts $\left(3.53 \mathrm{p} / 100 \mathrm{~km}^{2}\right)$ to the medium class, SPA Slovenský kras Mts $(2.74$ p/100 $\mathrm{km}^{2}$ ) to the interval between the medium and low density classes, and the remaining 3 SPAs (Nízke Tatry Mts, Tatry Mts and Volovské vrchy Mts) would not even achieve the low density class.

Upon comparing the abundance of the breeding populations of the lesser spotted eagle in the selected SPAs between 2000 and 2014 a 26\% decline was determined (Dravecký et al. 2015). One of the main reasons for this decline in the population is the loss and damage to breeding habitats in monoculture forests of spruce, mainly in central Slovakia. Spruce stands are highly vulnerable to wind calamities and damage is multiplied with subsequent forest management activities. The negative impact of forest management activities was also recorded in deciduous or mixed forests which were not affected by wind calamities. With the aim of stopping this negative trend a total of 151 were established protection zones around the nests of lesser spotted eagles in the surveyed period within the LIFE project; these provided protection for 119 breeding territories, representing approximately $17 \%$ of the lesser spotted eagle breeding population in Slovakia. In nests with an established protection zone a higher probability of successfully raising young was found in comparison with nests without such zones.

Yet despite the fact that in some countries the issue of protection zones is arranged by legislation (e.g. Germany, Poland, Lithuania and Estonia), no knowledge is yet known to us regarding an evaluation of the effectiveness of such established protection zones.

We can summarize the importance of establishing protection zones in the following points: 1) they make the land owner or user aware of the breeding of protected species and about the need for observing the specific conditions ensuring quiet during its reproductive period and at the same time conserving breeding habitats in a favourable state; 2) they determine the area for and timing of limitations of economic activities; 3) they stipulate the obligation of the land owner and user to consult with the State Nature Conservancy of the Slovak Re- 
public regarding the conducting of planned management activities in the area of an established protection zone; 4) they enable application of the umbrella effect in natural ecosystems, i.e. that through the protection of one species the protection of other species is also ensured. By establishing protection zones around the nests favourable conditions for undisturbed breeding of lesser spotted eagles are created along with long-term preservation of their breeding habitats and increased reproductive success of the entire population.

The average reproductive success during the fouryear period in the eight SPAs from 277 fledged young, 512 pairs present, 385 breeding pairs represented overall 0.51 juv./pair present, 0.69 juv./breeding pair and 1.37 juv. $/ 100 \mathrm{~km}^{2}$ (with an overall range of all eight SPAs of $5562.99 \mathrm{~km}^{2}$ ) (Tab. 4). The stated range of reproductive success falls within the Europe-wide average of 0.5-0.8 young/pair (Bergmanis et al. 1997). Nearly identical reproductive success was recorded in Latvia during the years 1988-2014, when from 1,178 analyzed nests, the reproductive ratio was 0.49 young/pair present and 0.74 young/breeding pair. In other countries the following reproductive success was determined: Estonia (0.56 juv./pair present, Väli 2012), Lithuania (0.60 juv./pair present, Treinys 2009), the German states of Brandenburg (0.65 juv./pair present, Böhner \& Langgemach 2004) and Mecklenburg-Pomerania (0.51 juv./pair present, Scheller et al. 2001) and Poland (0.69 juv./pair present, Mirski et al. 2013).

The core portion of the breeding population of $A$. pomarina within the species distribution range, located in Estonia, Latvia, Belarus and Lithuania, lives in a habitat of a predominately plains character with a mosaic of forests, meadows, pasturage, fields and wetlands at an altitude up to $350 \mathrm{~m}$ a.s.1. The highest altitude in the individual countries is as follows: Lithuania 293.8 $\mathrm{m}$, Latvia $311.6 \mathrm{~m}$, Estonia $318 \mathrm{~m}$ and Belarus $345 \mathrm{~m}$. According to Bergmanis et al. (1997) the species breeds in coniferous, mixed and deciduous forests, and also utilizes environments of damp meadows, pasturage, river valleys, swamplands and peat bogs, usually below an altitude of $400 \mathrm{~m}$ a.s.l. The breeding population of $A$. pomarina in Slovakia dwells in a habitat which is very different from that described above. In the Carpathian habitats breeding is recorded up to an altitude of 1000 m a.s.l. (Dravecký et al. 2015). This statement is in line with the results of this work, where the lowest situated nest was at an altitude of $150 \mathrm{~m}$ and the highest $950 \mathrm{~m}$ a.s.l. Similarly, the breeding population of $A$. pomarina in the Carpathian also rises to higher altitudes in Ukraine and in Romania, reaching up to $700 \mathrm{~m}$ a.s.l. in Ukraine (Domashevskyy et al. 2015).

Even though according to Bergmanis et al. (1997, 2015 ) the core portion of the population is located in the Baltic countries and Belarus below an altitude of $400 \mathrm{~m}$, a significant part of the population of $A$. pomarina within the European breeding territory distribution of the species is found in the Carpathians in Slovakia, Ukraine and Romania, namely: $600-800$ breeding pairs in Slovakia (Dravecký et al. 2015), 1,100-1,300 pairs in Ukraine (Domashevskyy et al. 2015) and 2,200 pairs in Romania (http://pomarina.ro/index.php?option=com content\&view $=$ article\&id $=66 \&$ Itemid $=65 \&$ lang $=\mathrm{EN})$.

\section{References}

Bělka T 2014: Orel křiklavý v České republice [Lesser spotted eagle in the Czech republic], 13. In: Anonymus (ed), Umíme žít s orly? Aneb jak se daří orlům v Česku a na Slovensku. Sborník příspěvků z konference, 12. března 2014, Zoologická zahrada Ostrava, 34. [In Czech]

Bergmanis U, Drobelis E \& Karaska D 1997: Aquila pomarina, lesser spotted eagle, 164-165. In: Hagemeijer EJM \& Blair MJ (eds), The EBCC Atlas of European breeding birds - their distribution and abundance. $\mathrm{T}$ and $\mathrm{AD}$ Poyser, London, 904.

Bergmanis U, Auniņš A, Petrinš A, Cirulis V, Granats J, Opermanis O \& Soms A 2015: Population size, dynamics and reproduction success of the lesser spotted eagle (Aquila pomarina) in Latvia. Slovak Raptor Journal, 9: 45-54. DOI: 10.1515/srj-20150003.

BirdLife International 2004: Birds in Europe: population estimates, trends and conservation status. Cambridge, UK: BirdLife International. (BirdLife Conservation Series No. 12), 374.

BirdLife International (2015) Species factsheet: Clanga pomarina. Downloaded from http://www.birdlife.org on April 1, 2015.

Danko Š, Darolová A \& Krištín A 2002: Rozšírenie vtákov na Slovensku [Birds Distribution in Slovakia]. Veda, Bratislava, 688. [In Slovak with English summaries]

Demko M, Krištín A \& Puchala P 2013: Červený zoznam vtákov Slovenska. Red list of birds in Slovakia. Tichodroma 25: 69-78 [In Slovak with English abstract] 
Domashevskyy S, Gavrilyuk M, Milobog Y \& Vetrov V 2015: Current status of the lesser spotted eagle in Ukraine, 92-93. In: Dravecký M \& Guziová Z (eds): Abstracts of contributions presented at the International Conference on the Conservation of the Lesser Spotted Eagle, Slovakia, 2014. Slovak Raptor Journal, 9: 71-93. DOI: 10.1515/srj-2015-0006.

Dombrovski VC \& Ivanovski VV 2005: New data on numbers and distribution of birds of prey in Belarus. Acta Zoologica Lituanica. 15: 218-227. DOI: 10.1080/13921657.2005.10512615.

Dravecký M, Maderič B \& Guziová Z 2011: Ochrana orla krikl'avého na Slovensku LIFE09 NAT/SK/000396. Správa z výsledkov monitoringu populácie orla krikl’avého $\mathrm{v}$ projektových územiach za rok 2011 [Conservation of the lesser spotted eagle in Slovakia LIFE09 NAT/SK/000396. Report from the results of lesser spotted eagle population monitoring in project areas in 2011]. Ochrana dravcov na Slovensku (RPS), Bratislava, 40. [In Slovak] Downloaded on April 1, 2015 from http://www.dravce.sk/apomarina/images/LIFE_APOM Monitorovacia sprava 2011.pdf

Dravecký M, Maderič B \& Guziová Z 2012: Ochrana orla krikl'avého na Slovensku LIFE09 NAT/SK/000396. Správa z výsledkov monitoringu populácie orla krikl'avého v projektových územiach za rok 2012 [Conservation of the lesser spotted eagle in Slovakia LIFE09 NAT/SK/000396. Report from the results of lesser spotted eagle population monitoring in project areas in 2012]. Ochrana dravcov na Slovensku (RPS), Bratislava, 45. [In Slovak] Downloaded on April 1, 2015 from http://www.dravce.sk/apomarina/images/LIFE_\%20 APOM_Monitorovacia\%20sprava_2012.pdf

Dravecký M, Maderič B \& Guziová Z 2013: Ochrana orla krikl'avého na Slovensku LIFE09 NAT/SK/000396. Správa z výsledkov monitoringu populácie orla krikl'avého $\mathrm{v}$ projektových územiach za rok 2013 [Conservation of the lesser spotted eagle in Slovakia LIFE09 NAT/SK/000396. Report from the results of lesser spotted eagle population monitoring in project areas in 2013]. Ochrana dravcov na Slovensku (RPS), Bratislava, 45. [In Slovak] Downloaded on April 1, 2015 from http://www.dravce.sk/apomarina/images/LIFE_APO-

MARINA_Monitorovacia_sprava_2013.pdf

Dravecký M, Maderič B \& Guziová Z 2014: Ochrana orla krikl'avého na Slovensku LIFE09
NAT/SK/000396. Správa z výsledkov monitoringu populácie orla krikl'avého $\mathrm{v}$ projektových územiach za rok 2014 [Conservation of the lesser spotted eagle in Slovakia LIFE09 NAT/SK/000396. Report from the results of lesser spotted eagle population monitoring in project areas in 2014]. Ochrana dravcov na Slovensku (RPS), Bratislava, 46. [In Slovak] Downloaded on April 1, 2015 from http://www.dravce.sk/ apomarina/images/LIFE\%20AP\%202014\%20Monitorovacia\%20sprava.pdf

Dravecký M, Maderič B, Topercer J, Kicko J, Danko Š, Karaska D, Guziová Z \& Šotnár K 2015: Abundance, distribution and trend of the lesser spotted eagle (Aquila pomarina) breeding population in Slovakia. Slovak Raptor Journal 9: 7-44. DOI: 10.1515/srj-2015-0001

European Terrestrial Reference System, ETRS: Downloaded on May 1, 2015 from http://etrs89.ensg.ign.fr/ and http://aves.vtaky.sk/sk/about/oatlase

Hagemeijer EJM \& Blair MJ (eds) 1997: The EBCC Atlas of European breeding birds - their distribution and abundance. T and AD Poyser, London, 904.

Karaska D \& Danko Š 2002: Orol krikl'avý (Aquila pomarina) [Lesser spotted eagle], 195-197. In. Danko Š, Darolová A \& Krištín A (eds), Rozšírenie vtákov na Slovensku [Bird distribution in Slovakia]. Veda, Bratislava, 688. [In Slovak with English summary]

Kicko J 2013: Demekológia a habitatové nároky dravcov v Západnych Karpatoch [Demecology and habitat requirements of birds of prey in Západne Karpaty Mts]. Dizertačná práca. Prírodovedecká fakulta UK, Bratislava, 114. [In Slovak with English abstract]

Kroupová V 1980: Topografické podklady Databanky fauny Slovenska [Topographic data of Databank of Slovak Fauna]. Správy Slovenskej zoologickej spoločnosti SAV 7: 23-27. [In Slovak]

LIFE08 NAT/RO/000501-Conservation of Aquila pomarina in Romania, Downloaded on May 1, 2015 from http://pomarina.ro/index.php?option=com_content\&view $=$ article\&id $=66 \&$ Itemid $=65 \&$ lang $=\mathrm{EN}$.

Meyburg B-U, Graszynski K, Langgemach T, Sömmer P \& Bergmanis U 2008: Cainism, nestling management in Germany in 2004-2007 and satellite tracking of juveniles in the lesser spotted eagle (Aquila pomarina). Slovak Raptor Journal 2: 53-72. DOI: 10.2478/v10262-012-0018-2.

Mazúr E \& Lukniš M 1980: Geomorfologické jednotky Slovenska 1:500 000. [Geomorphological units of 
Slovakia 1:500 000], 54-55. In: Mazúr E (ed), Atlas SSR [Atlas of Slovakia]. SAV a SÚGK, Bratislava. 296. [In Slovak with English and Russian summary]

Mirski P, Cenian Z, Wojciak J, Zawadzka D, Lontkowski J \& Stój M 201 3. Lesser spotted eagle national action plan for Poland. Draft version. Olsztyn, Eagle Conservation Committee, 118.

Pongrácz Á \& Szitta T 2015: Current situation and population trend of the lesser spotted eagle (Aquila pomarina) in Hungary. Slovak Raptor Journal, 9: 65-69. DOI: 10.1515/srj-2015-0005.

R Development Core Team 2013. R: A language and environment for statistical computing. R Foundation for Statistical Computing, Vienna. Downloaded on May 1, 2015 from http://www.R-project.org/

Scheller W, Franke E, Matthes J, Neubauer M \& Schwarnber Ch 2001: Verbreitung, Bestandsentwicklung und Lebensraumsituation des Schreiadlers Aquila pomarina in Mecklenburg-Vorpommern. Vogelwelt 1 22: 233-246.

Rybanič R, Šutiaková T \& Benko Š (eds) 2004: Významné vtáčie územia na Slovensku. Územia významné $\mathrm{z}$ pohl'adu Európskej únie [Important Bird Areas of European Union importance in Slovakia. Spoločnost' pre ochranu vtáctva na Slovensku. Society for the protection of birds in Slovakia]. Bratislava. 219. [In Slovak with English summary].

Stloukal E 2001: Databanka Fauny Slovenska - stav a nové prírastky databáz v roku 2001 [Current status and new data in Databank of Slovak fauna in year 2001]. Folia faunistica slovaca 6: 145-168. [In Slovak with English abstract]

Štátna ochrana prírody Slovenskej republiky, Natura 2000: Downloaded on May 1, 2015 from http://www.sopsr.sk/natura/index1.php?p=4\&lang=sk $\& \mathrm{sec}=1 \& \mathrm{cpt}=1$
Štastný K \& Bejček V 2003: Červený seznam ptáku České republiky [The Red List of birds of the Czech Republic], 95-1 21 . In: Plesník J, Hanzal J \& Brejšková L (eds), Červený seznam ohrožených druhu České republiky. Obratlovci [Red List of Threatened Species in the Czech Republic. Vertebrates]. Príroda 22, Praha. 1 84. [In Czech with English and German summaries]

Štastný K, Bejček V \& Hudec K 2006: Atlas hnízdního rozšírení ptáku v České republice 2001-2003 [Atlas of breeding birds in CSSR 2001-2003], Aventinum, Praha, 463. [In Czech with English summary]

Treinys R, Drobelis E, Šablevicius B, Naruševicius V \& Petraška A 2007: Changes in the abundance of the lesser spotted eagle (Aquila pomarina) breeding population in Lithuania in 1980-2006. Acta Zoologica Lithuanica 17: 64-69. DOI: 10.1080/ 13921657.2007.10512817.

Treinys R 2009: Habitat use and population status of the lesser spotted eagle Aquila pomarina on the northwestern periphery of the distribution range. Summary of doctoral dissertation. Vilnius University, Vilnius, 32.

Tucker GM \& Heath MF 1994: Birds in Europe: their conservation status. Cambridge, UK: BirdLife International (BirdLife Conservation Series no. 3), 600.

Väli Ü 201 2: Factors limiting reproductive performance and nestling sex ratio in the lesser spotted eagle Aquila pomarina at the northern limit of it range: the impact of weather and prey abundance. Acta Ornithologica 47: 1 57-1 68. DOI: $10.3161 /$ $000164512 \times 662269$.

Väli Ü 2015: Monitoring of spotted eagles in Estonia in 1994-2014: Stability of the lesser spotted eagle (Aquila pomarina) and decline of the greater spotted eagle (A. clanga). Slovak Raptor Journal 9: 55-64. DOI: $10.1515 /$ srj-2015-0004. 
Slovak Raptor Journal 2015, 9: 127-145. DOI: 10.1515/srj-2015-0010.

(C) Raptor Protection of Slovakia (RPS)

Appendix 1. Average altitude of nest trees $(n=215)$ of lesser spotted eagles (Aquila pomarina) found in orographic units in Slovakia. The arrangement of the orographic units (located within eight SPAs) is in descending order.

Appendix 1. Priemerné nadmorské výšky zistených hniezdnych stromov ( $n=$ 215) orlov kriklavých (Aquila pomarina) v orografických celkoch na Slovensku. Zoradenie orografických celkov (nachádzajúcich sa v ôsmich CHVú) v zostupnom poradí.

\begin{tabular}{|c|c|c|c|c|}
\hline \multirow[t]{2}{*}{$\begin{array}{l}\text { oragraphic unit / } \\
\text { orografický celok }\end{array}$} & \multirow{2}{*}{$\begin{array}{l}\text { No. of nests / } \\
\text { počet hniezd } \\
n\end{array}$} & \multicolumn{3}{|c|}{$\begin{array}{l}\text { altitude (m a. s. I) / } \\
\text { nadm.výška (m n. m.) }\end{array}$} \\
\hline & & priemer & $\min$. & $\max$ \\
\hline Podbeskydská brázda & 3 & 912.00 & 893 & 942 \\
\hline Kozie chrbty & 2 & 904.00 & 864 & 944 \\
\hline Oravské Beskydy & 7 & 837.00 & 791 & 950 \\
\hline Liptovská kotlina & 15 & 829.87 & 756 & 897 \\
\hline Podbeskydská vrchovina & 18 & 774.78 & 622 & 929 \\
\hline Ďumbierske Tatry & 5 & 747.00 & 698 & 780 \\
\hline Král'ovohol'ské Tatry & 1 & 736.00 & 736 & 736 \\
\hline Oravská Magura & 2 & 724.00 & 720 & 728 \\
\hline Oravská kotlina & 18 & 664.61 & 603 & 733 \\
\hline Čierna hora & 2 & 576.00 & 542 & 610 \\
\hline Volovské vrchy & 8 & 531.25 & 378 & 693 \\
\hline Rožňavská kotlina & 2 & 510.00 & 446 & 574 \\
\hline Slovenský kras & 13 & 479.92 & 371 & 638 \\
\hline Laborecká vrchovina & 66 & 418.27 & 231 & 575 \\
\hline Slanské vrchy & 25 & 400.88 & 230 & 542 \\
\hline Košická kotlina & 8 & 392.25 & 352 & 449 \\
\hline Vihorlatské vrchy & 11 & 362.09 & 280 & 530 \\
\hline Ondavská vrchovina & 4 & 260.75 & 231 & 292 \\
\hline Východoslovenská pahorkatina & 5 & 244.60 & 150 & 340 \\
\hline$\sum$ & 215 & 595.01 & 150 & 950 \\
\hline
\end{tabular}

